صور من إعجاز البيان فى فواصل القرآن دراسة فى بلاغة الفاصلة

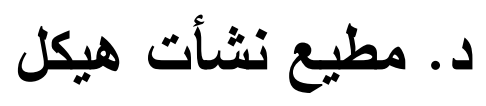




\section{مقدمة :-}

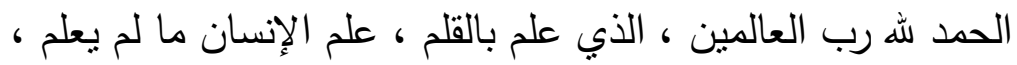

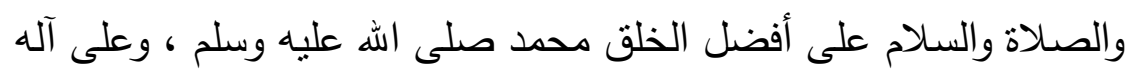

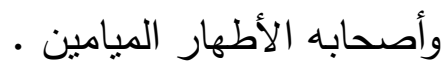

ويعد ...

فلقد حظيت فواصل القرآن الكريم باهنمام بالغ من العلماء قديماً

وحديثاً 1 ، فتتاولوها من نواح كثيرة ، حيث وضحوا الفرق بين معنى الفاصلة

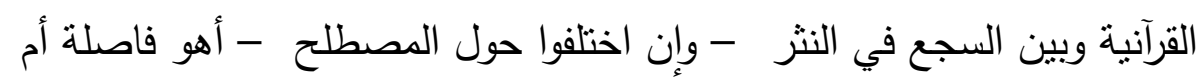

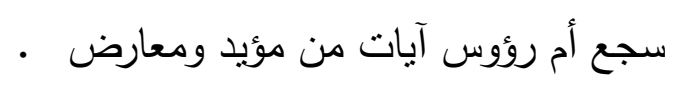

لكن ما يلفت النظر أن معظم هذه الكتابات لم تربط في أغلبها بين الفاصلة وبين اتساقها مع المعنى الجزئي للآية الواردة فيها أو مع السياق العام للسورة كلها . - الس

وهو ما حدا بي أن أكتب هذه الدراسة تحت عنوان " صور من إعجاز

البيان في فواصل القرآن " دراسة فى بلاغة الفاصلة ، وذلك أن الفواصل القرآنية

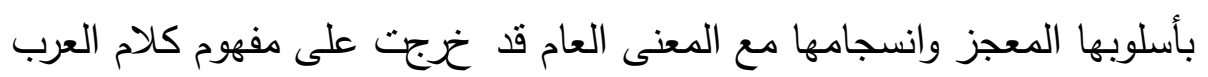
وفنون قولهم شعراً ونثراً . باسل

وهذا ما لاحظه العلماء قديماً ، فالرماني مثنلاً في كتابه " النكث في

إعجاز القرآن " يقول " فإن العادة كانت جارية بضروب من أنواع الكلام

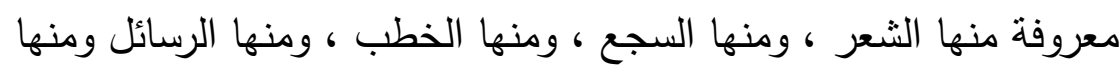
المنثور الذي يدور بين الناس في الحديث ، فأنى القرآن بطريقة مفردة ، خارجة

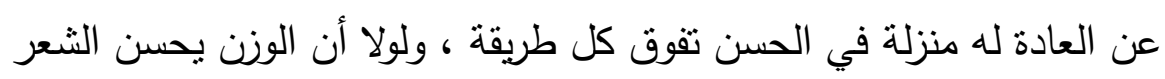
لنقصت منزلته في الحسن نقصاناً عظيماً ، ولذلك من جاء بغير الوزن فرن ونه 
المعروف في الطباع الذي من شأنه أن يحسن الكلام بما يفوق الموزون ، فهو معزة " معروف في 1

وخلاصة القول السابق أن الرماني ، نسب إعجاز الفواصل القرآنية

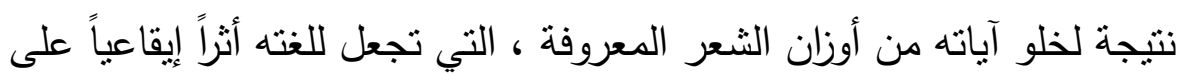

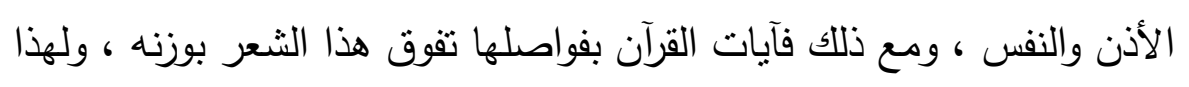

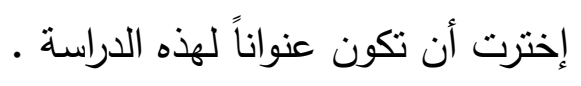

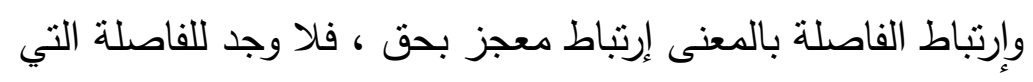

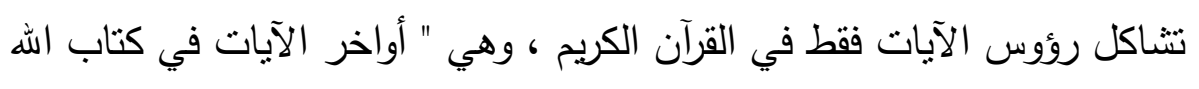

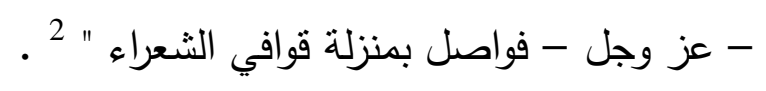

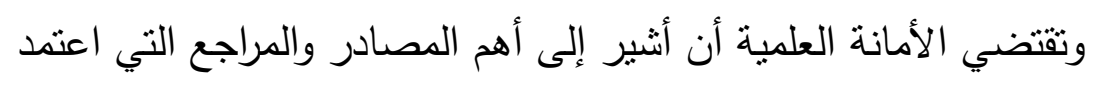

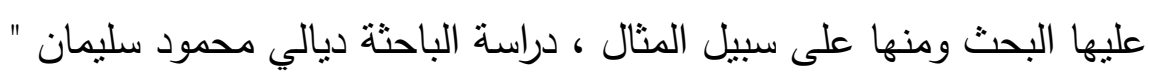

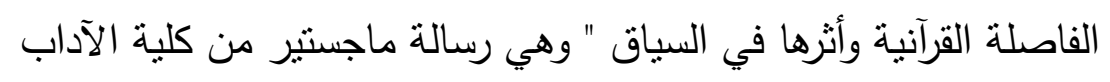

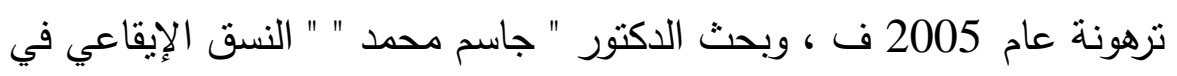

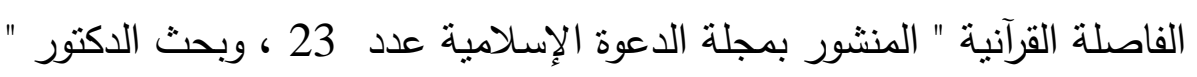
ساسي إمحمد " عن التغاير التصريفي في القراءات في نفس العدد ، وغيرها .

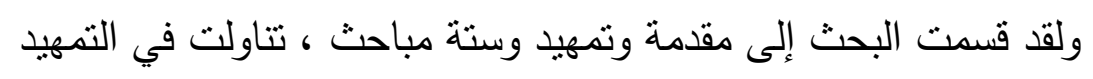

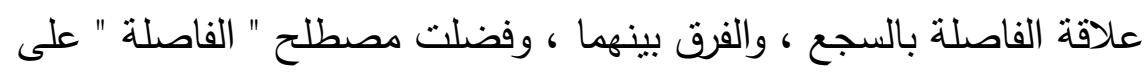

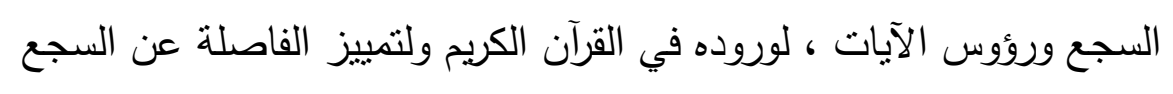

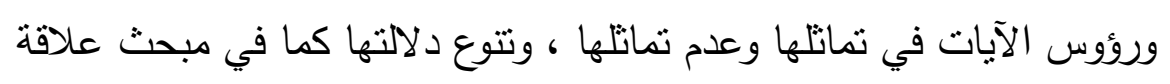

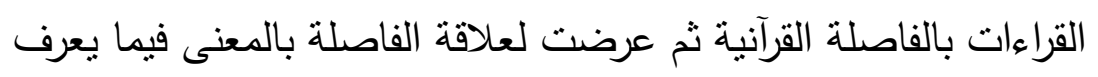
بالتمكين والتصدير و التوشيح والايغال . 
أما المباحث فقد تتاولت في المبحث الأول علاقة الفواصل بالأسلوب

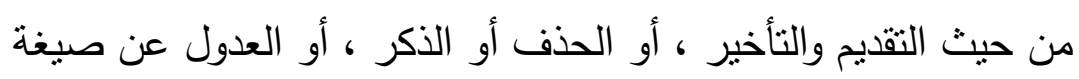
وتقضيل صيغة أخرى عليها .

وتتاولت في المبحث الثانى تلك الفواصل المختلطة لآيات متشابهة في

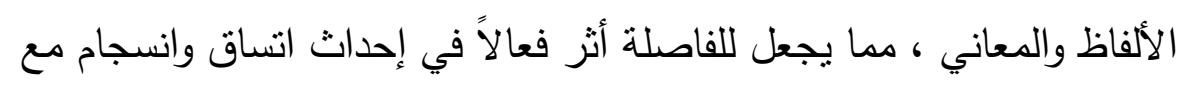

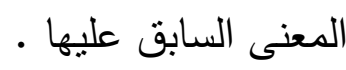

و تتاولت في المبحث ال ثالث علاقة الفواصل بعلم القراءات ، حيث

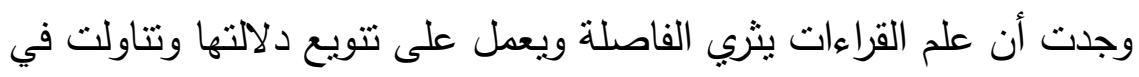

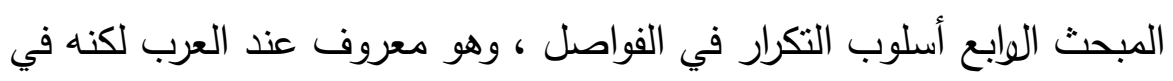

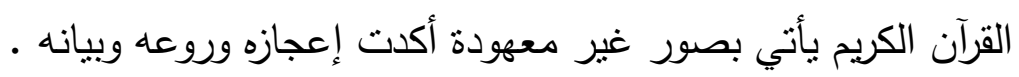

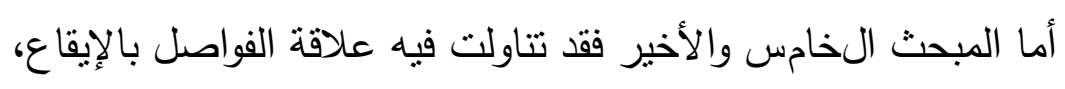
وللإيقاع علاقة قوية بمبحث التكرار السابق ، مما جعلني أربط بين تكرار

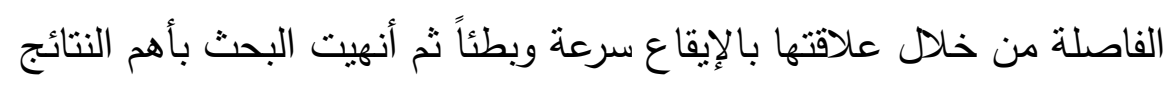

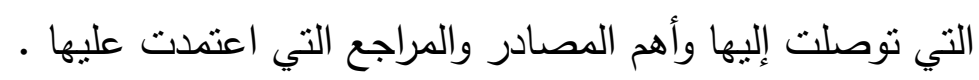
وعلى الله قصد السبيل 
الفاصلة بين التعريف والتوظيف :-

يعتبر أبو الحسن الأشعري أول من قال بنظام الفاصلة ، وتمسك بهذا

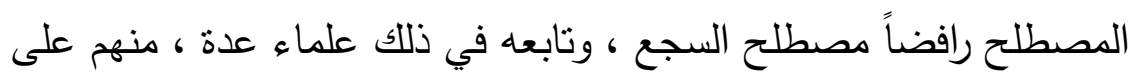
سبيل المثال " الزمخشري " ، الذي ربط بين الفاصلة والمعنى العام للآية ، فكانت ل له لفتات ذكية ، وتقسيرات نافذة إلى لب السياق القرآني ، يقول في قوله تعالى

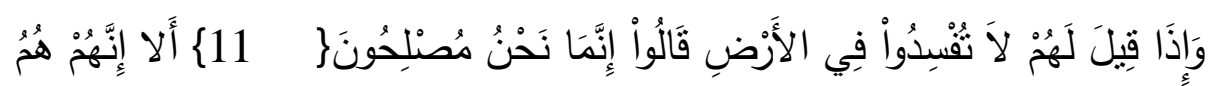

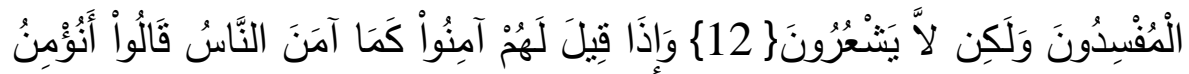

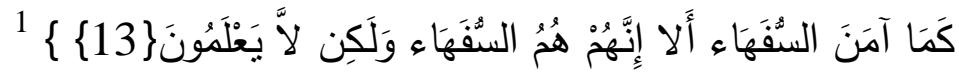

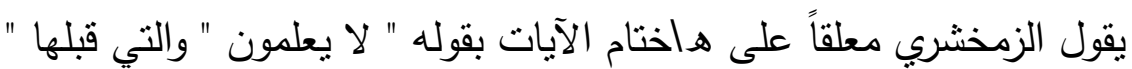
لا يشعرون " : فإذا قلت ، فلم فصلت هذه الآية بـ " لا يعلمون " والتي قبلها بـ " لا يشعرون " ؟ قلت : لأن أمر الديانة والوقوف على أن المؤمنين على الحق وهم على الباطل يحتاج إلى نظر واستدلال حتى يكسب الناظر معرفة 2 . وفي السيرة النبوية ما يؤكد نفاذ بصيرة الصحابة وحسن استدلالهم وقوة بديهته ، هذا من ناحية ومن ناحية أخرى يؤكد مدى تتاسق وارتباط الفاصلة

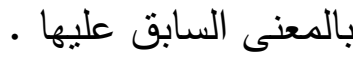
فقد روي عن الرسول صلى الله عليه وسلم أنه كان يملي على زبد بن

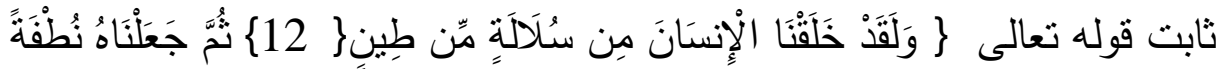

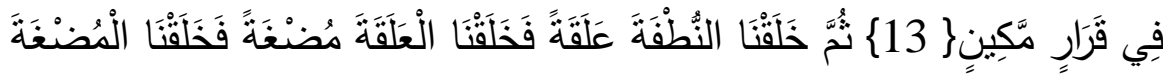

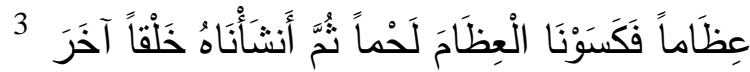
وكان الصحابي "معاذ بن جبل " جالساً ، فقال ببديهته وحسن طبعه " فَتََبَرَكَكَ اللَّهُ أَحْسَنُ الْخَالقِينَ " فابتسم النبي صلى الله عليه وسلم وقال "بها ختمت 3 " 
مما يجعل مصطلح " الفاصلة " أنفع وأصح من غيره ، فالقرآن أنشار

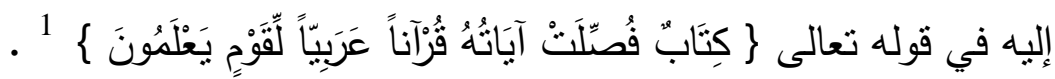

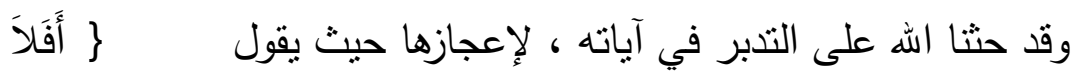

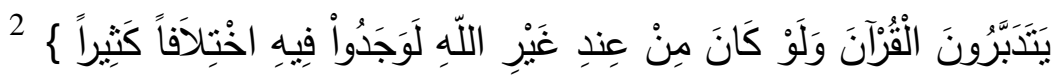

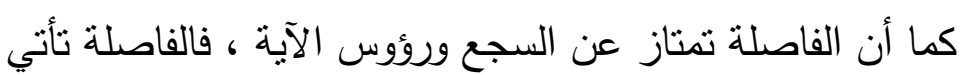
متماصلة وغير منمانلة ، وقد تتفرد عما قبلها لتختم الآيات كالمقطع

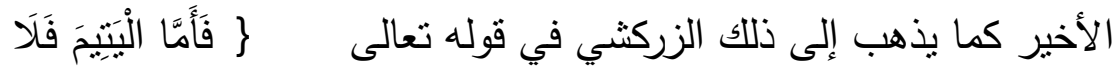

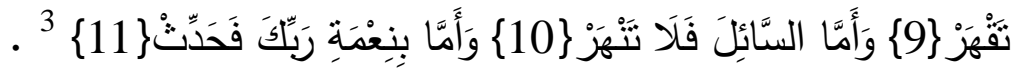
، إلى جانب أنه لاسجع في القرآن على راي معظم العلماء وقديماً وحديثاً

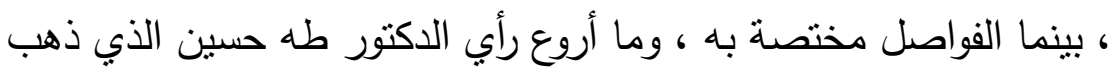

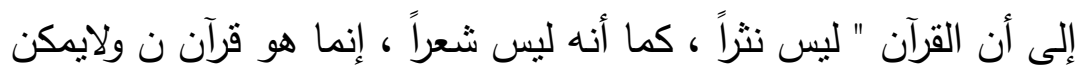

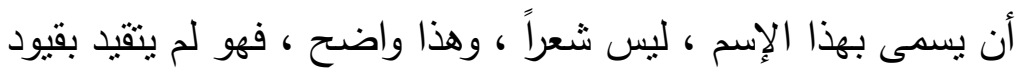

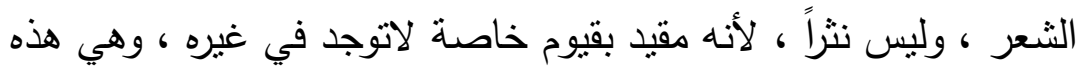

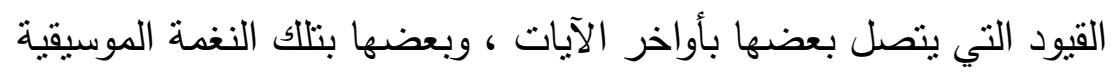

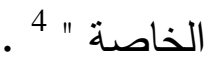

ويجعل السيوطي فرقاً بين الفاصلة القرآنية ورؤوس الآية حيث يقول " أما

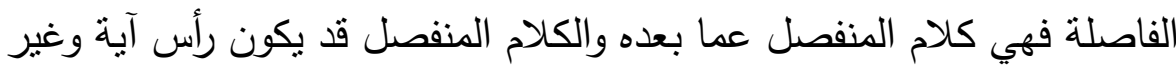
رأس ، وكل رأس آية فاصلة ، وليس كل فاصلة رأس آية ، فالفاصلة تعم النوعين

وقد ظفرت علاقة الفاصلة بالمعاني بدراسات كثيرة 6 فربطوا به بلاغتها وحسنها بما يعرف بالتمكين والتصحير والتوشيح والإيغال .

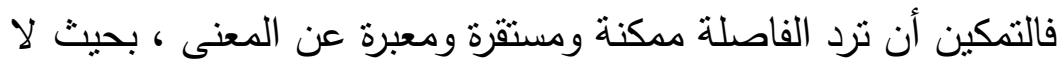

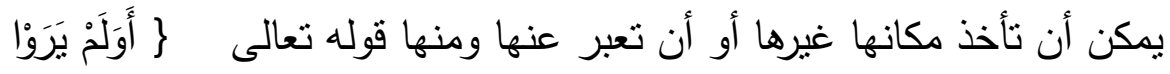




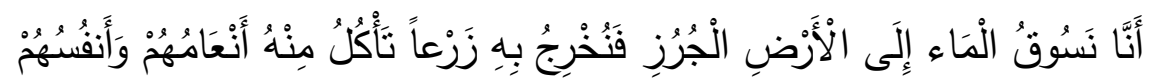

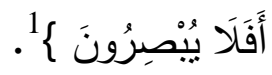

فقد بدأت الآية بما يرشح أن تكون فاصلتها

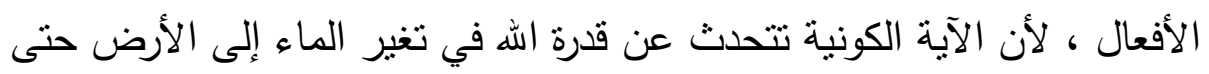

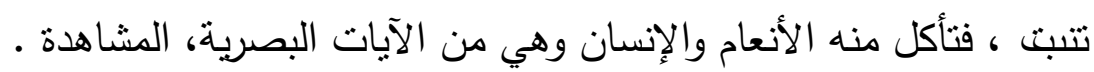

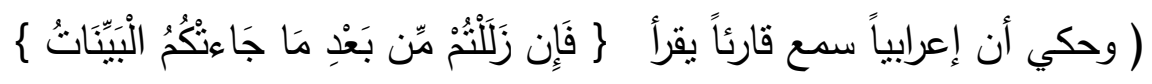

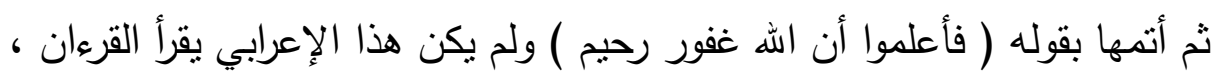

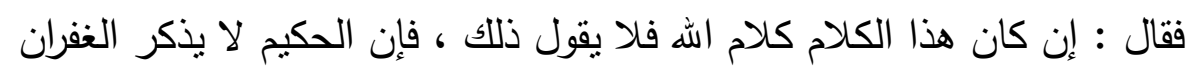

$$
2 \text { عند الزلل لأنه اغراء عليه) }
$$

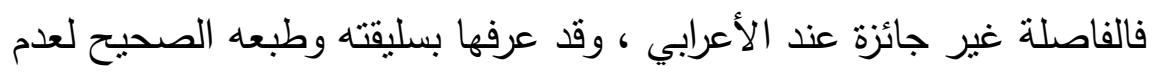

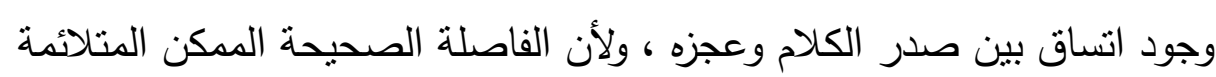

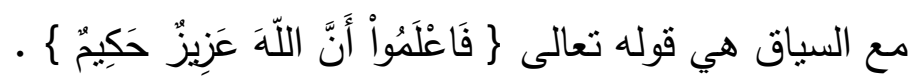

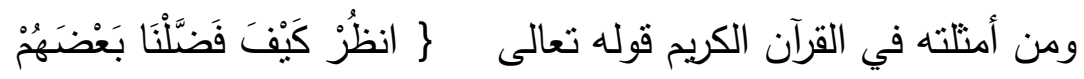

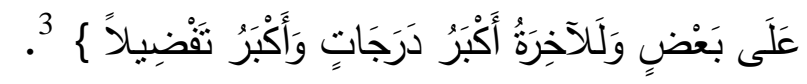

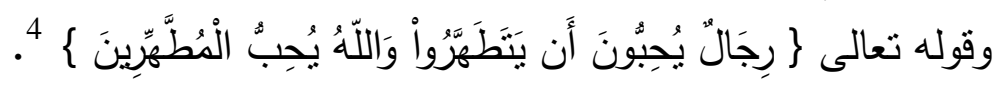

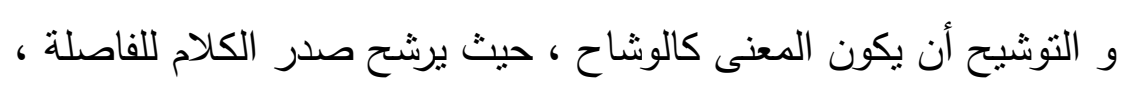
ويوجد فيه ما يدل على فحوى الفاصلة ، وهو ما جعلهم يقولون فيه :

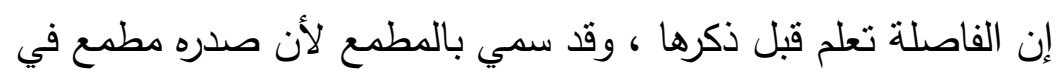

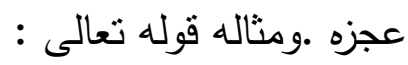

$$
\begin{aligned}
& 1 \text { - سورة السجدة الآية } 27 \text { ـ } \\
& 2 \text { - أنظر البرهان في علوم القرآن ص } 95 \text { ـ }
\end{aligned}
$$

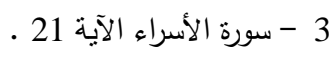

$$
\begin{aligned}
& 4 \text { - سورة التوبة الآية } 108 \text { ـ }
\end{aligned}
$$




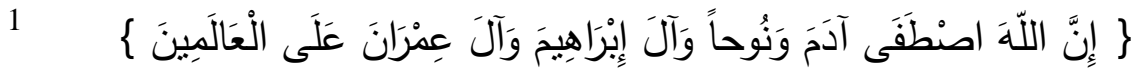
فالفاصلة أوحت بالمفضول قبلها وهم " آدم ونوح وآل إبراهيم وآل عمران " ولأن

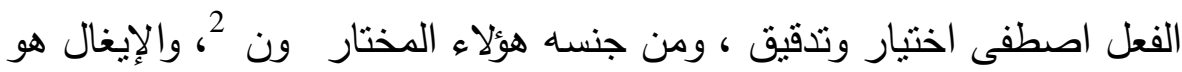

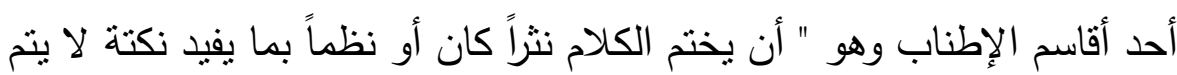
المعنى يدونها وقد سمي بذلك لأن المتكلم تجاوز المعنى الذي هو أخذ فيه وبلغ

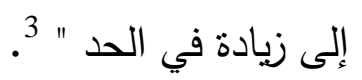

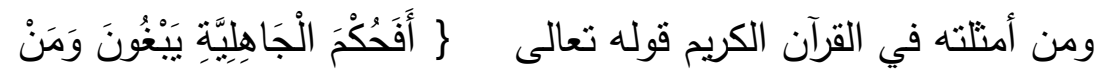

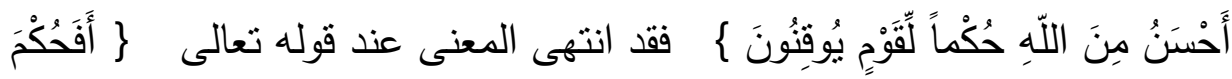

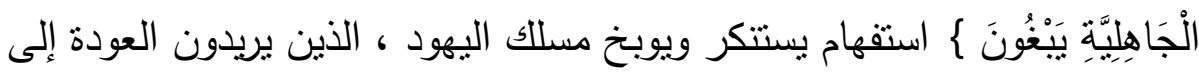
حكم الجاهلية ، ثم أنت الفاصلة لتؤكد أفضلية حكم الله تعالى لقوم يوقنون به ، وبطيعونه .

ومما سبق ينبين مدى حرص العلماء على مصطلح " الفاصلة " وذلك من

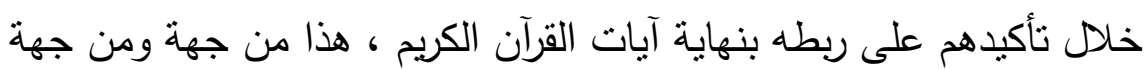
أخرى من خلال ربط تلك الفاصلة بالمعنى ، وهنا يستبين الفرق بين السجع

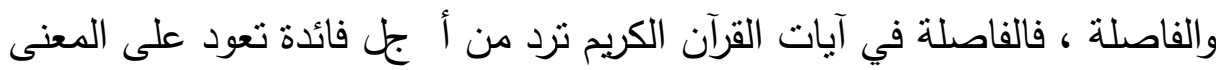
والأسلوب والسياق وهو ما سوف نتيينه من خلال التطبيق التالي على أساليب منتوعة للفاصلة . ولذلك فقد قسمت الدراسة إلى عدة مباحث تحت عنوان " فواصل " ، وحاولت قدر جهدي أن أربط بين إعجاز هذه الفواصل وما أدت إليه من فائدة ترتبط بسياقها المتسق مع الإيقاع الكلي للسورة .

$$
1 \text { - سورة آل عمران الآية } 33 \text {. }
$$

2- أنظر ابن الأصبع المصري " بديع القرآن " ص 90-91-91 . 3- الثريف الجرجاني " التعريفات " ص لص لـ 50 . 
ولما قصرت الدراسة على الناحية الأسلوبية ، فقد وجهتها للبحث عن علاقة الفواصل القرآنية بالأسلوب المصاحب لها ، حيث وردت أساليب قرآنية خالفت المعهود في الجملة العربية ليتسق مع السياق •

" كأن يتقدم المتأخر لمراعاة الفاصلة أو يؤخر المنقدم لل غٔض نف نفسه ،

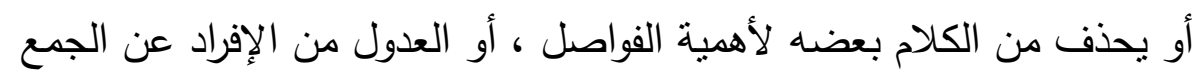
أو من الجمع إلى الإفراد وغير ذلك من الأساليب " 1 . كما وجدت فواصل ترتبط بعلم القراءات حيث اختلف العلماء حول صيغتها مما أدى إلى اختلاف الدلالة وإثراء المعنى .

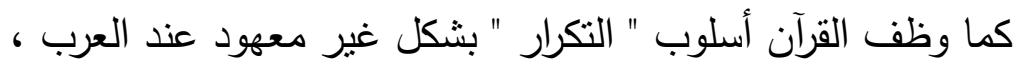

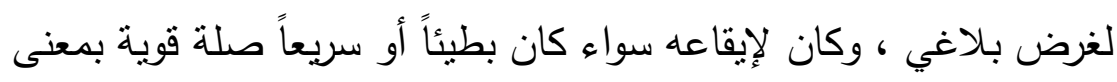
الآية . وسوف أتتاول بالتحليل بعض هذه الصور التي ورد فيها تقديم الألفاظ وتأخير غيرها لفائدة بلاغية . 
1

أ- التقديم والتأخير :

لايمكن بأي حال من الأحوال أن يكون لتقديم كلمة أو تأخير غيرها عنها أدنى صلة بمراعاة رؤوس الآية فقط ، ولو بحن بلثنا في أمثلة التقديم والتأخير لظهر لنا مدى العلاقة القوية بين هذا التقديم والتأخير وبين المعنى الكلي المستفاد من السورة من خلال علاقة هذا التقديم بما سبقه . قال تعالى في سورة النازعات

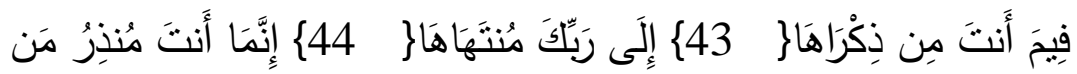

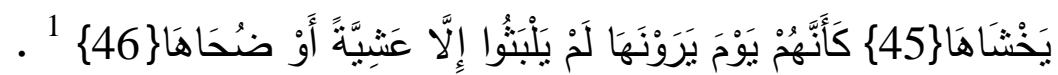
حيث ذهب الزمخشري في تفسير الكثاف أن المقصود قصر مدة لبثهم ، كأنها لم تبلغ يوماً كاملاً ، ولما نرك اليوم إضافة عشيته 2. والحقيقة أن المعنى ولو قصد فيه قصر المدة ومراعاة الفاصلة عشية على تلى معناها ، فإن إنساقها عجيب بين هذا التقديم وبين الدلالة الكلية لسورة

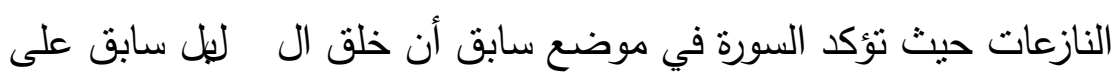

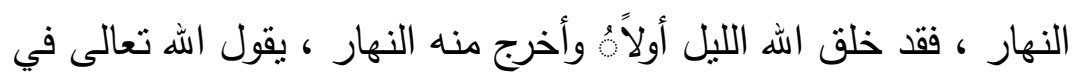

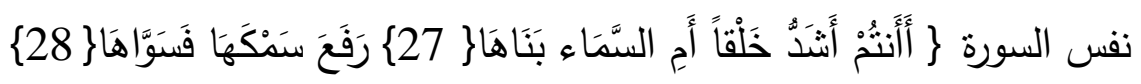
وَأَغْطَشَ لَيْلَهَ وَأَخْرَجَ ضُحَحَاهَا مَاءهَا

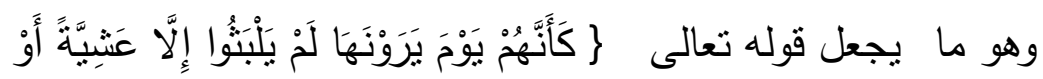

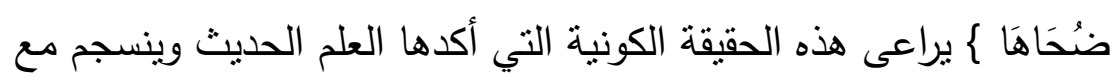
السياق العام لسورة النازعات ، و ل الع علاقة للتقديم والتأخير بمراعاة الفاصلة المنتهية بالهاء الممدودة 4 - . 


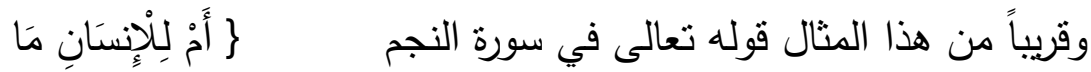

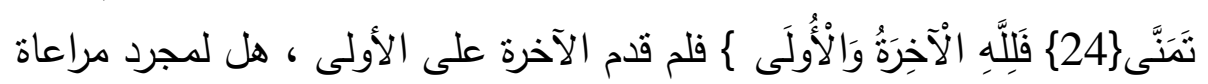

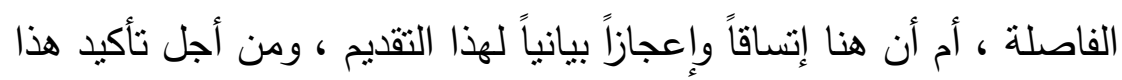

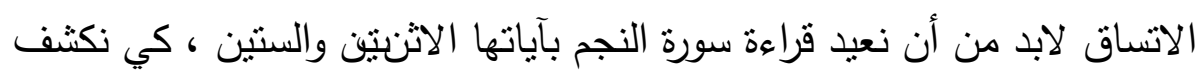
سر هذا التقديم . لالد نان

ومما لاثثك فيه أن الآخرة مقدمة على الأولى في آيات كثيرة من القرآن

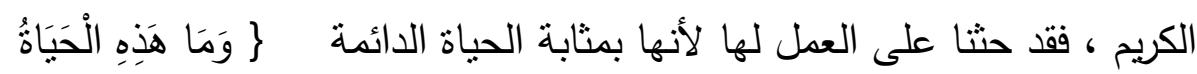

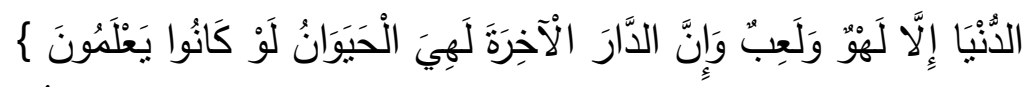

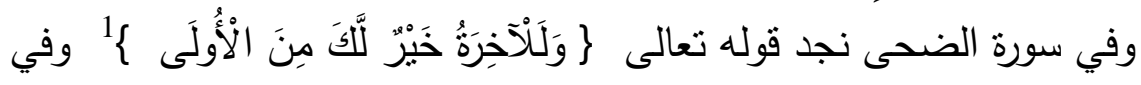

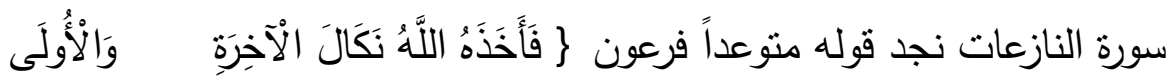

فأنظر إلى ددى دقة التتاسب وإعجاز الخطاب القرآني ، وسورة النجم

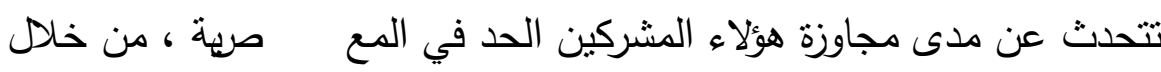

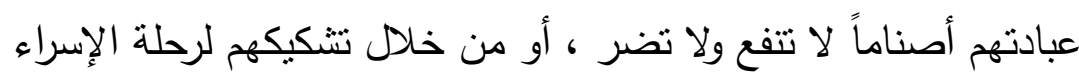

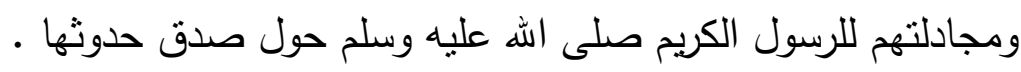

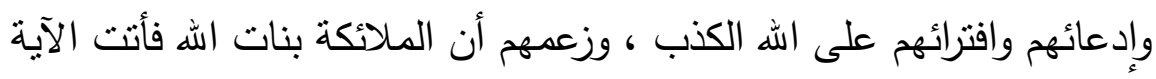

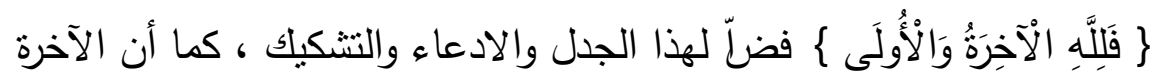

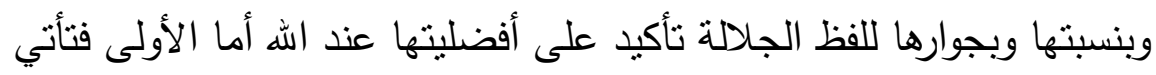

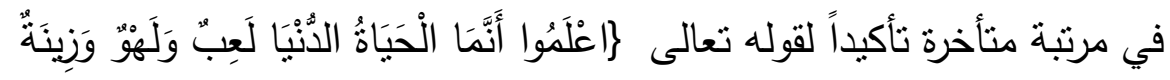

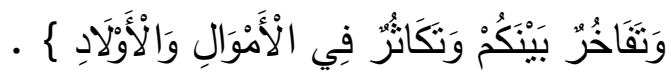

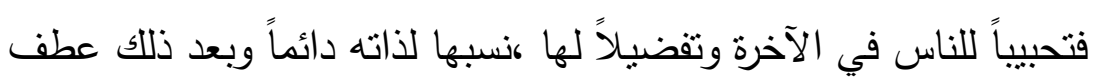
الدنيا عليها . 
ومن صور النقديم المشهورة التي رأى فيها العلماء مراعاة الآيات للفاصلة

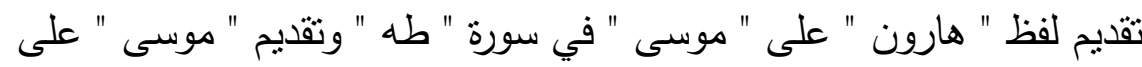

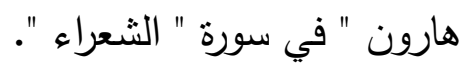

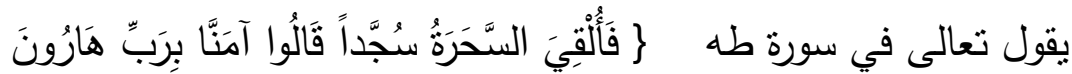

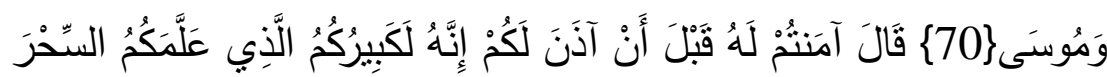

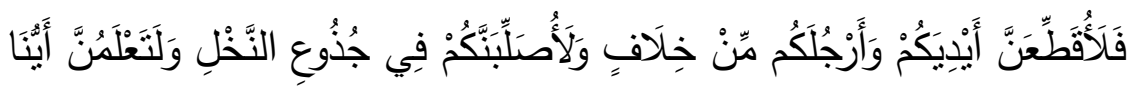

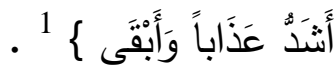

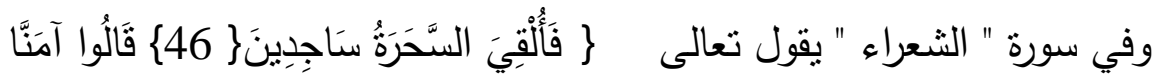

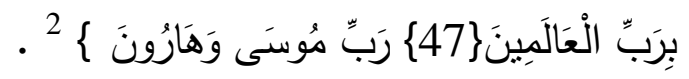

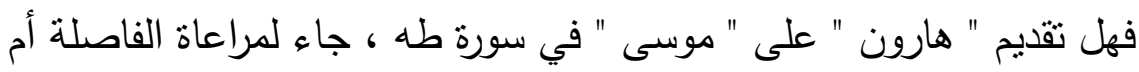
أن ذلك يقتضيه السياق ويلزمه المعنى العام للسورة .

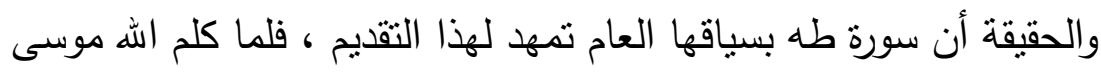

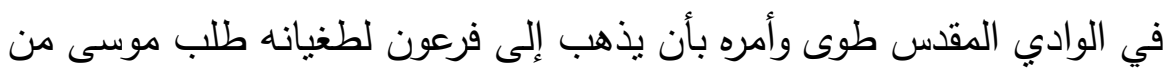

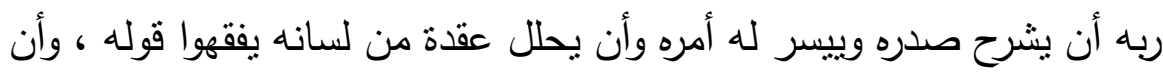

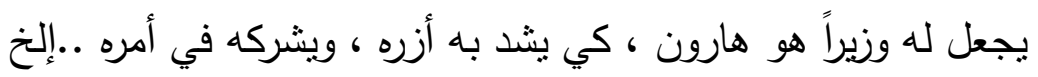

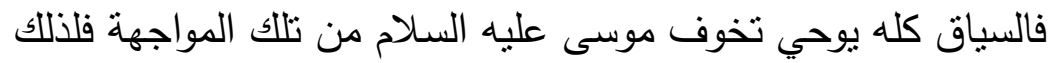
يطلب مؤازرة هارون له على الرغم من شدة خوفهما .

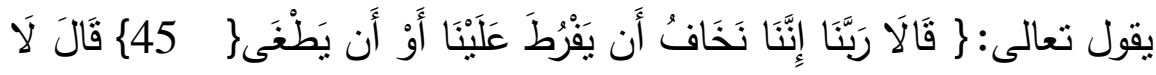

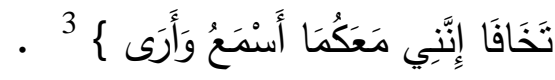
فالموقف والسياق كله موقف خوف ورهبة ، خوف من موسى وأخيه من

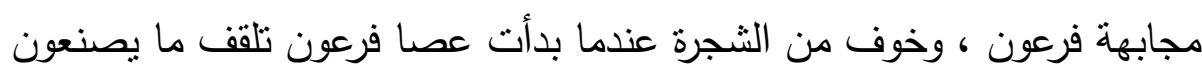

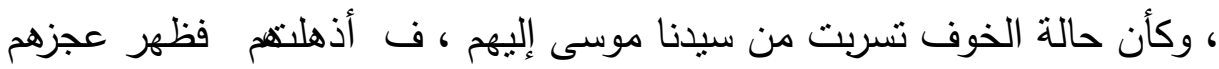

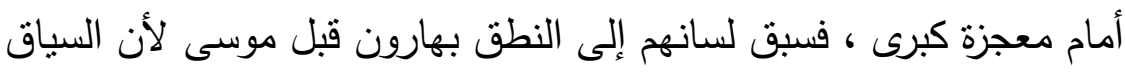


بستلزم ذلك الاضطراب وعدم التوفيق في ترتيب الأفضل هذا من ناحية ، ومن

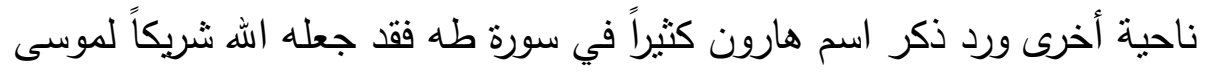

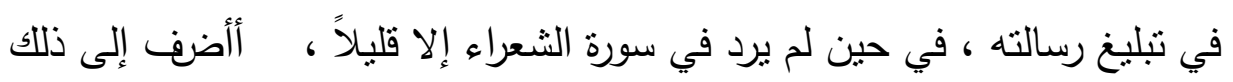

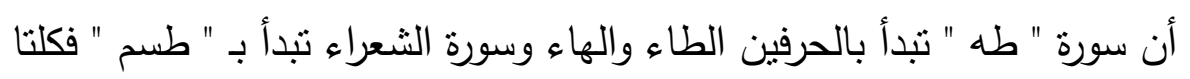

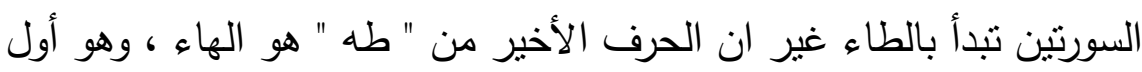

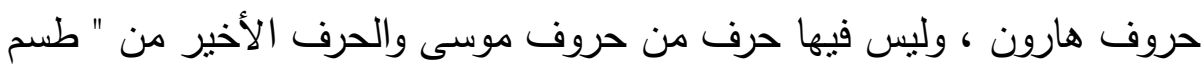

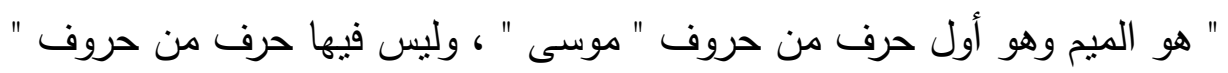
هارون " أفلا يزيد حسناً على حسن تقديم هارون على موسى في سورة طه ،

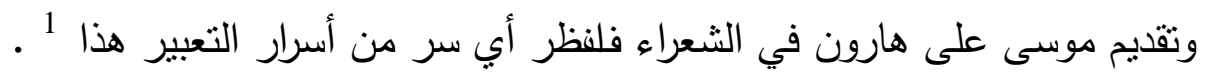

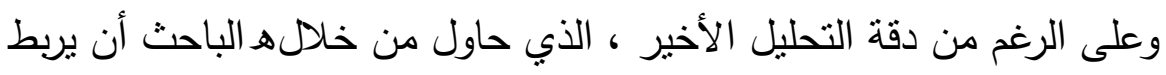

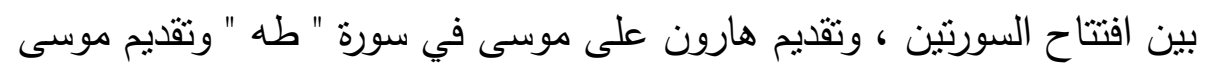
على هارون في سورة " الثعراء " ، إلا أنه وعلى الرغم من دقته وحسن استدلاله

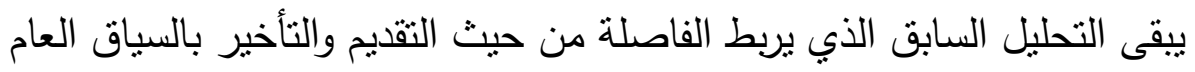
والمعنى المستفاد من السورة كله هو الفيصل المادي المحسوس والمقبول عقلاً.

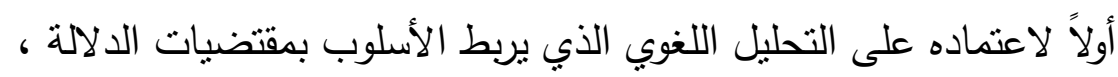

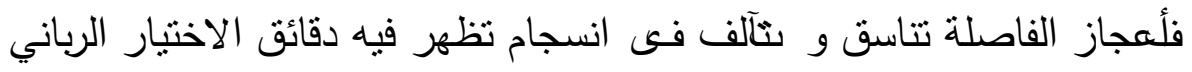

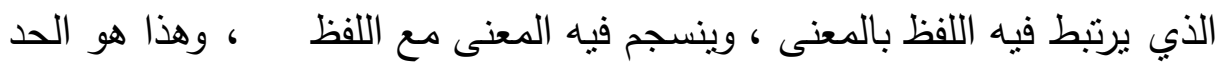
الفاصل بين فنية البلاغة كما تجلوها الفواصل القرآنية بدلالتها المعنوية المرهفة

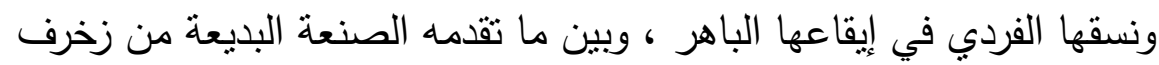

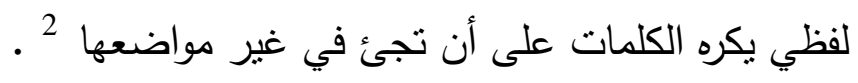

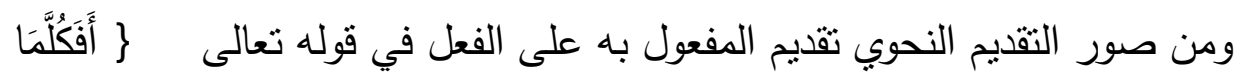

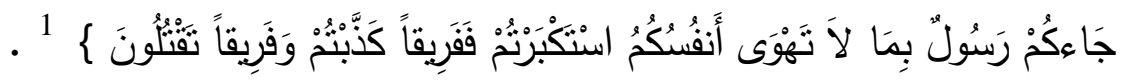


فقد ذهب كثير من العلماء أن التقديم لنواحي رؤوس الآيات 2 على الرغم

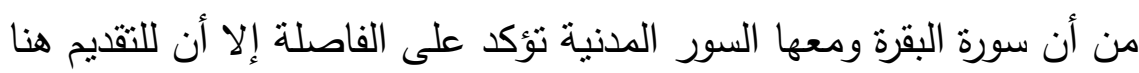
ميزة دقيقة وهي أن الآيات في معظمها تقوم على هذا التقديم ففي قوله تعالى ل

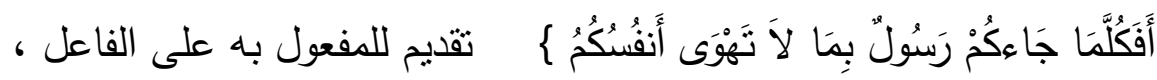

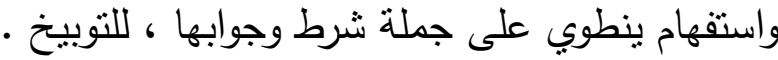
ومن ثم أراد الله تعالى تطويل هذا التوبيخ وتتويعه من خلال مخالفة طبيعة الجملة لفناً وتأكيداً لفظاعة فعلهم من تكذيهم وقتلهم للأنبياء .

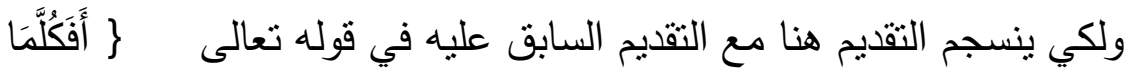

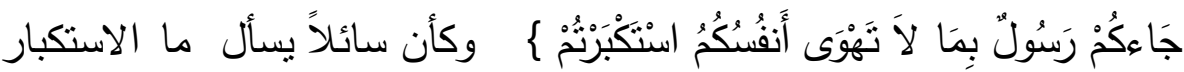

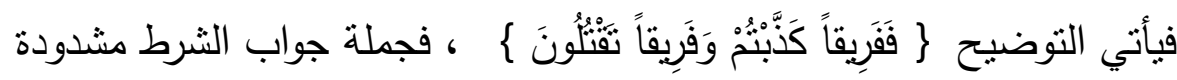
إلى جملة فطلها وكاثشفة لها ، لأنها تبين نوع الاستكبار نوبيخاً له وتحقيقاً

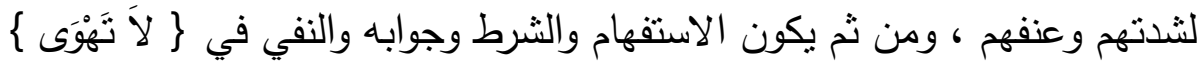
والفصل والتقديم مبرز الهذه الأفعال السيئة وبذلك يكون الفصل هنا مشدوداً لبعضه ولا يمكن الاستغناء بأي كلمة منه والاكتفاء بما قبلها ، لأن السؤال الهال

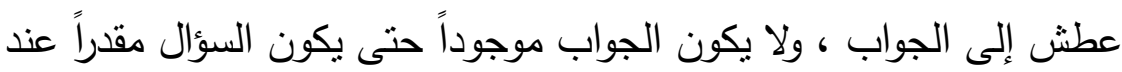

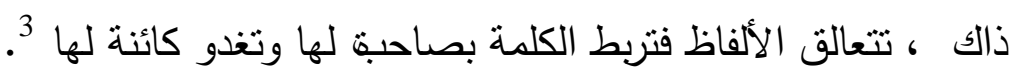

\section{الفواصل وأسلوب الحذف :-}

وهو أحد الأساليب التي أنشار إلى أهيتها عبد القاهر الجرجاني في دلائل الإعجاز ، وابن الأثير في المنل السائر 1 . .

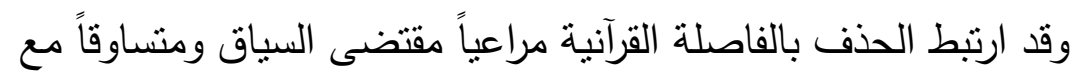

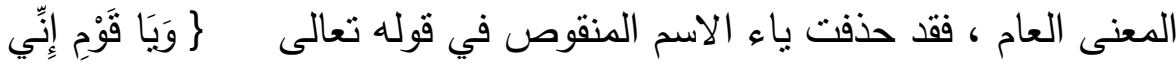

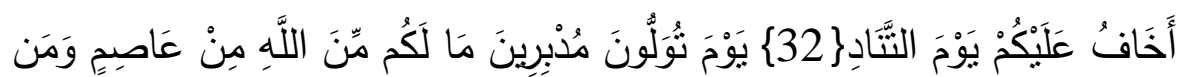

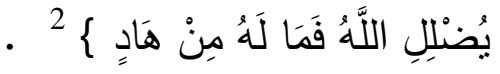


ويرى الزمخشري في الكثاف أن الحذف للإيجاز المتتاغم مع فواصل الآيات السابقة 33

إلا أننا نرى أن في حذف الياء ميزة أخرى دقيقة تضاف إلى مشاكلة رؤوس

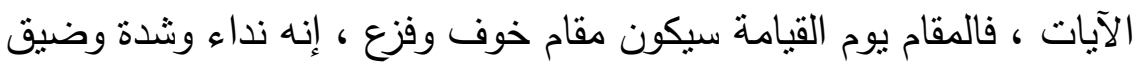

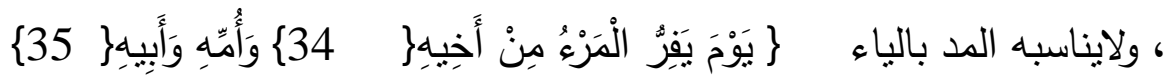

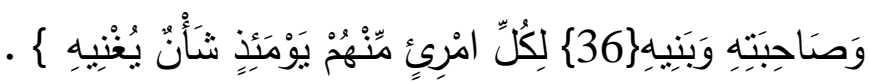

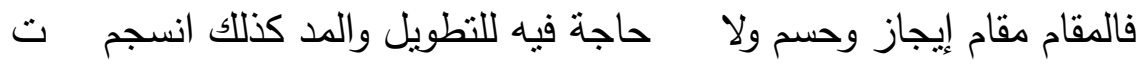

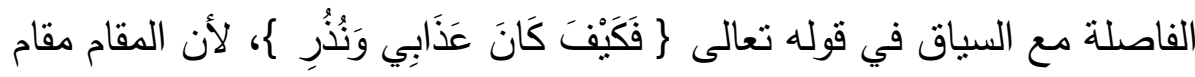

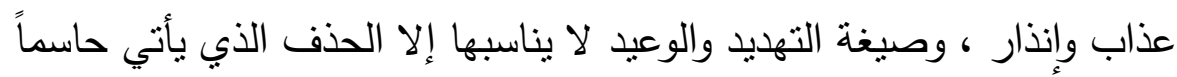

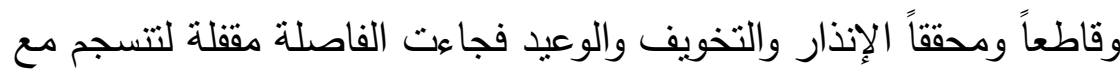

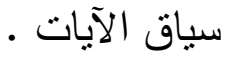

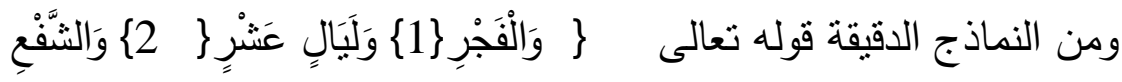

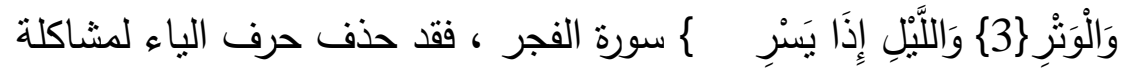

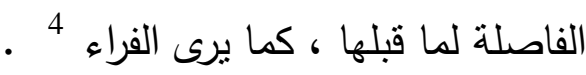

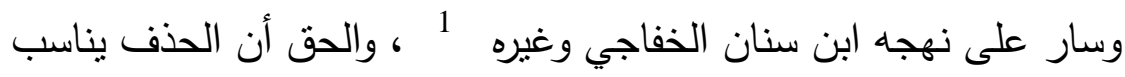
المعنى العام ، حركة الليل ، وانسيابهوقصره ، وعدم إحساس الإنسان بحركته

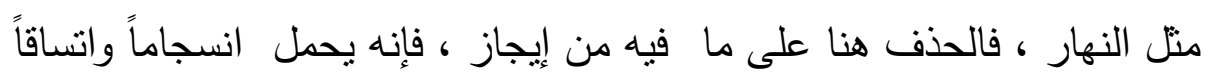

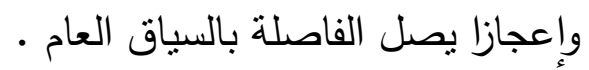

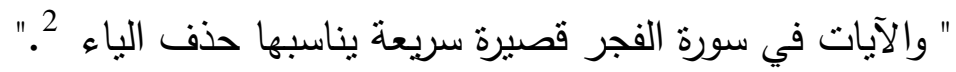

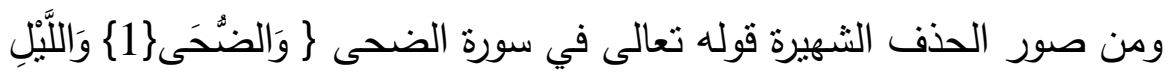

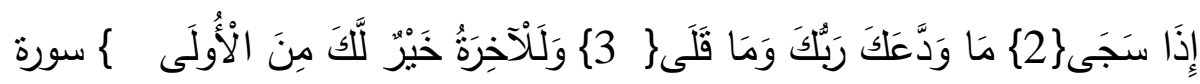

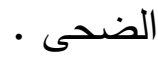


حيث يذهب الفزله في كتابه " معاني القرآن " إلى أن المقصود في قوله وما

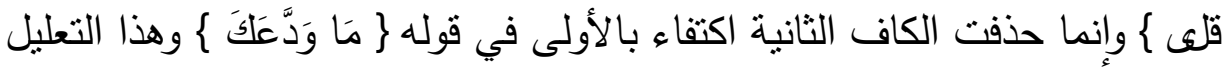
يتفق مع مباحث على النحو التي ترى عدم الحاجة إلى تكرار الكاف مادام المعنى

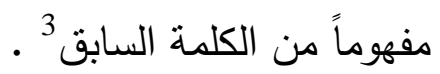

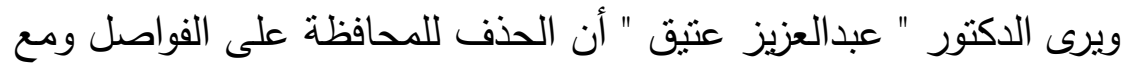
أن الفاصلة القرآنية قد راعت المشاكلة وعدم التكرار اكتفاء بالكاف السابقة ، إلا الا

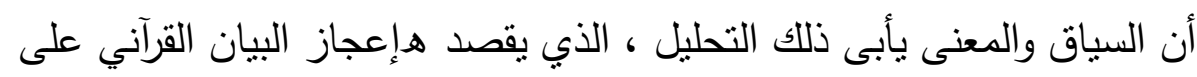

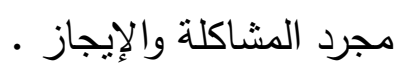

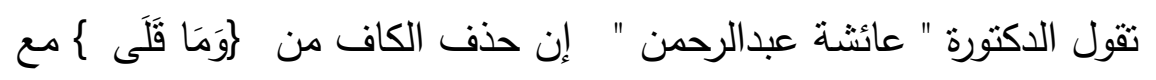

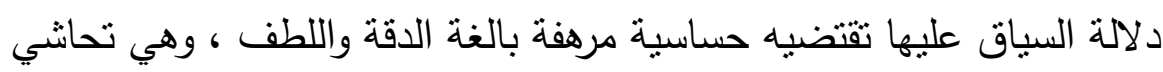
خطابه تعالى رسوله المصطفى في موقف الإيناس بصريح القول : وماقلالك ،

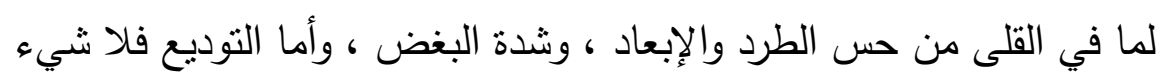

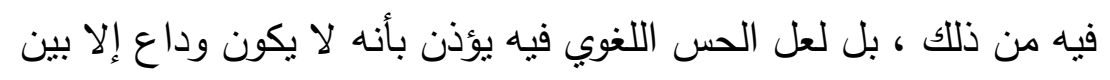

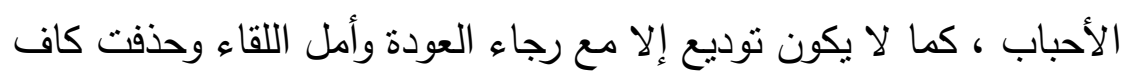

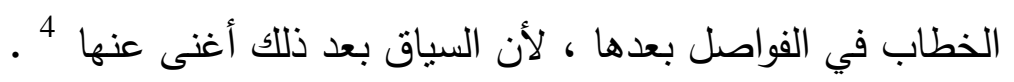

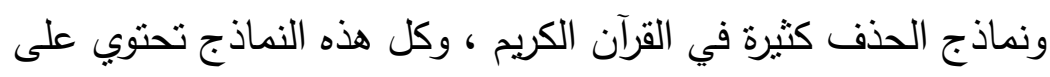

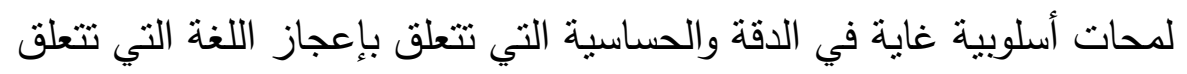

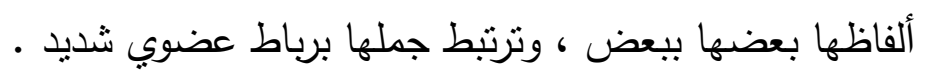

\section{ج- الفواصل وتغيير الصيغة :}

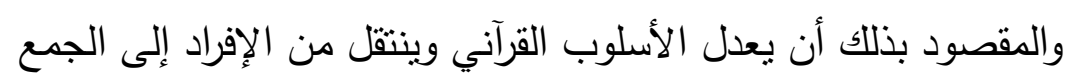

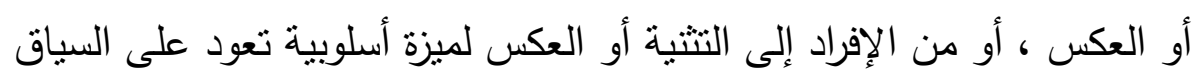

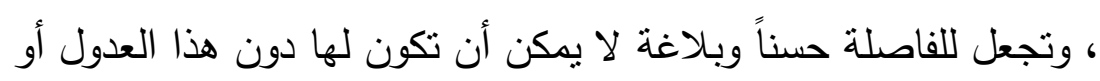
تغيير وضع الصيغة المتعارف عليها . 


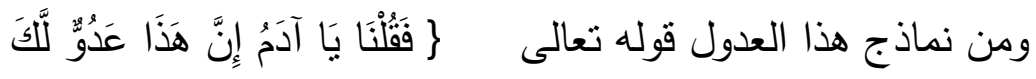

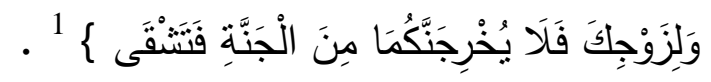

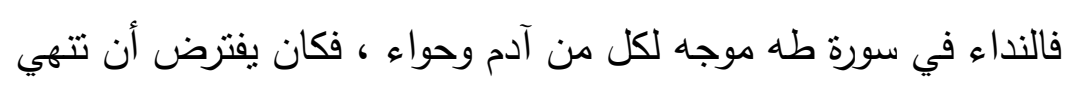

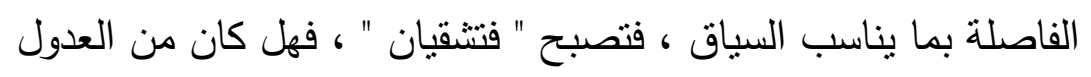

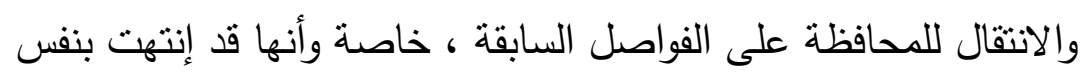

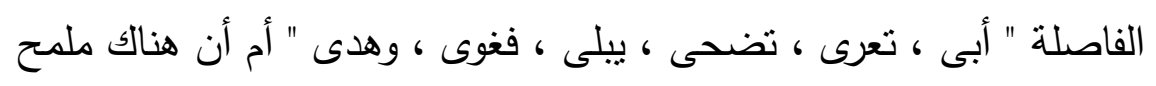

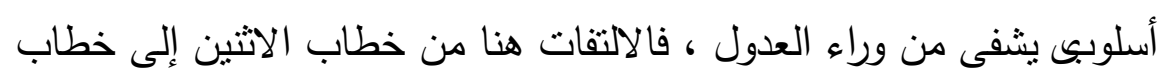

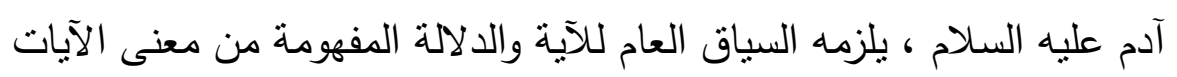

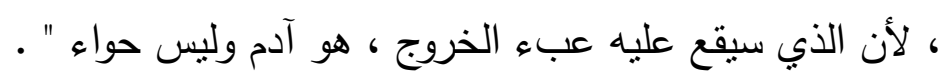

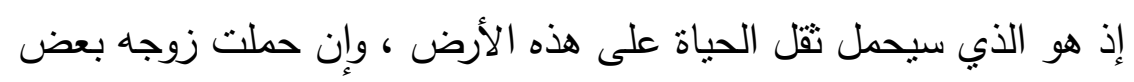

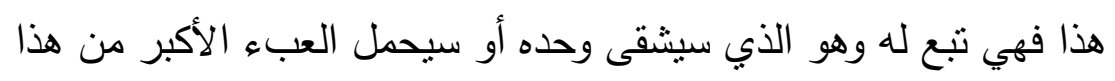

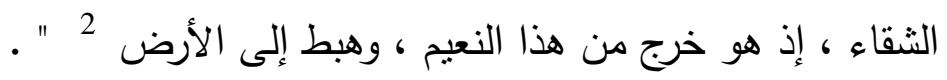

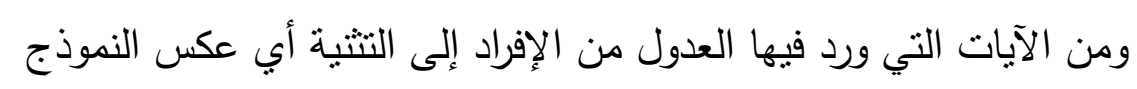

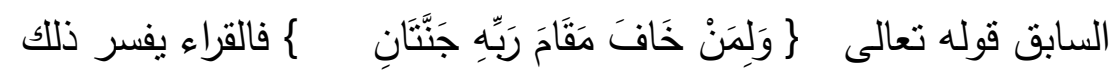

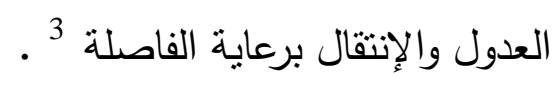

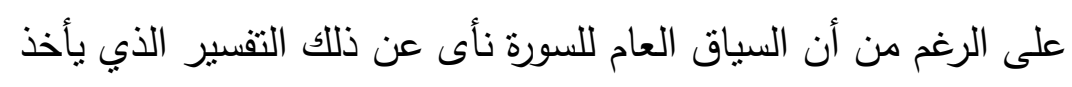

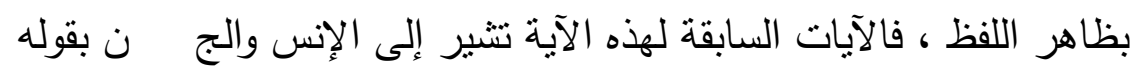

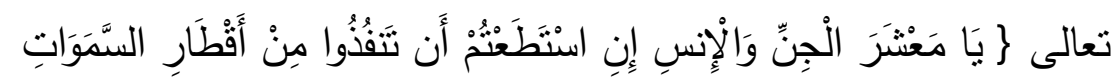

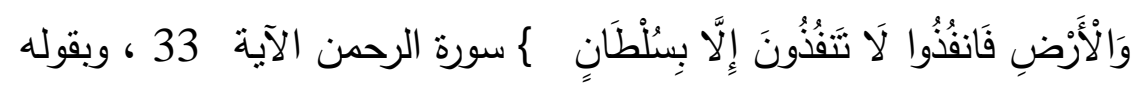

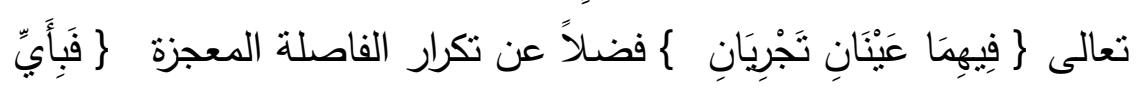

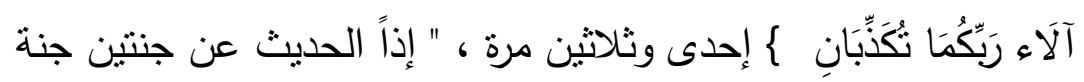

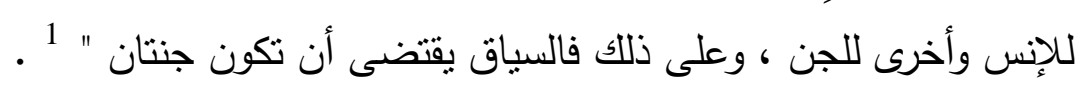


وقد يعدل الخطاب القرآني من الدفرد إلى الجمع أو من الجمع إلى الدفرد لغرض بلاغي يفهم من السياق العام للآيات القرآنية .

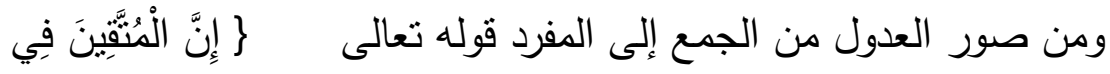

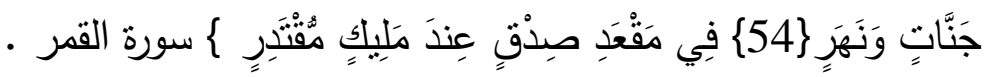

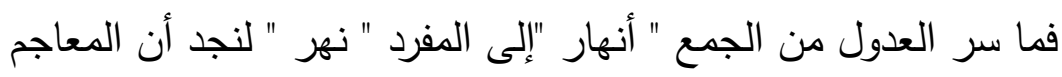

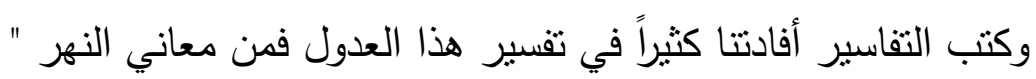

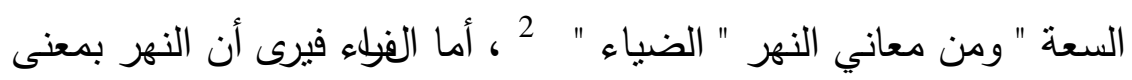
أنهار " ونهر معناه أنهار " . " وهذه المعاني كلها مراد ة مطلوبة ، فإن المتقين في جنات وأنهار كثيرة "نهاه

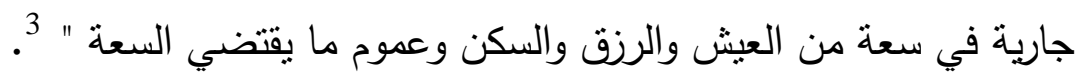

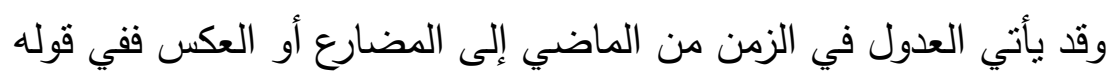

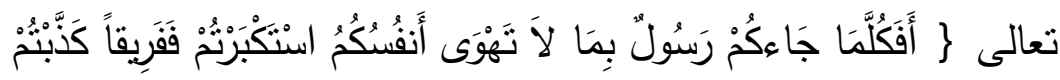

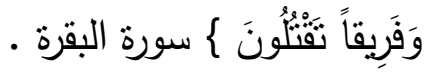

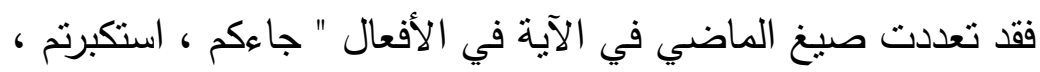

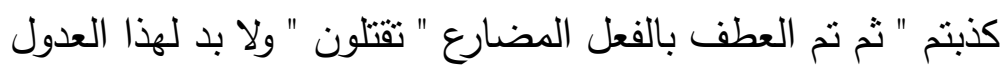

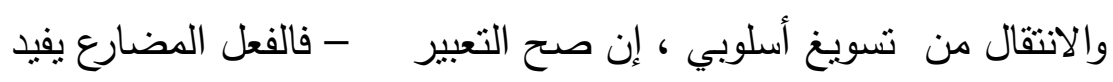

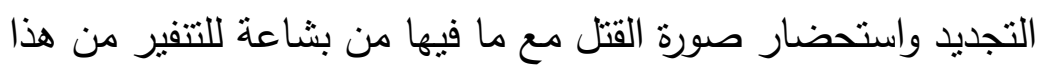
الفعل الفظيع والمشين إلى التحليل الذي جاء في مبحث التقديم السابق ${ }^{4}$. 


\section{3- فواصل مختلفة لآيات متشابهة :}

وهذا النوع من الفواصل يتكرر كثيراً في آيات القرآن ، حيث تتتابه الآيتان لكن تختلف في الفاصلة في كل منهما ، لتتسق مع المعنى المتلبس بلألفاظ ، ولتتسجم مع السياق العام للسورة كلها .

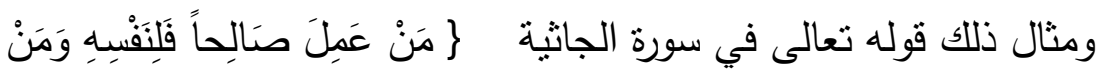

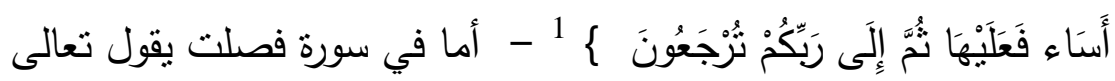

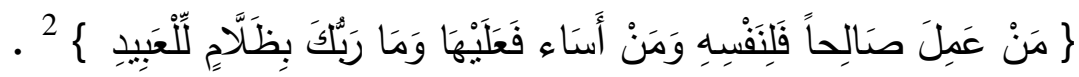
فسورة فصلت تتحدث آياتها عن فريقين ، فريق المؤمنين الذين يسبحون له له بالليل والنهار ولا يسئمون وفريق الكا فرين الذين يلحدون في آياته ،

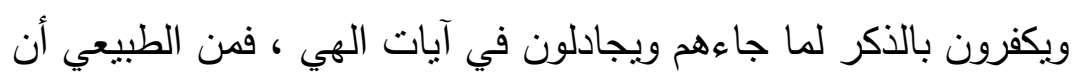

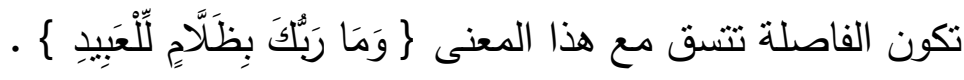

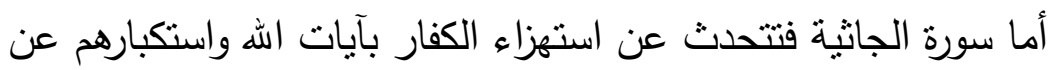
الإيمان 3 ، رغم آياته الكونية المختلفة من اختلاف الليل والنهار ، وما

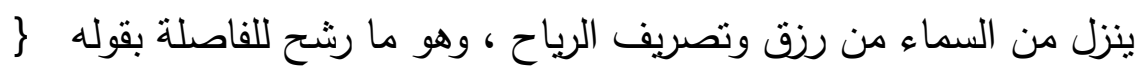

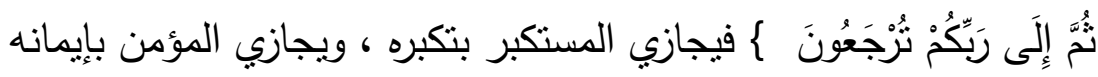

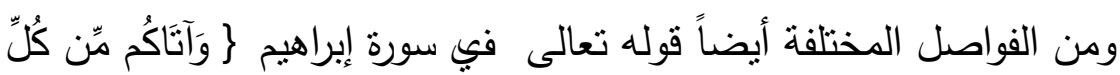

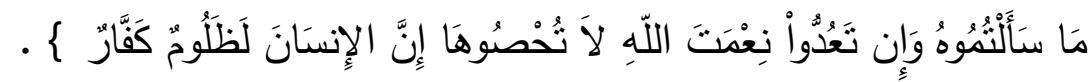

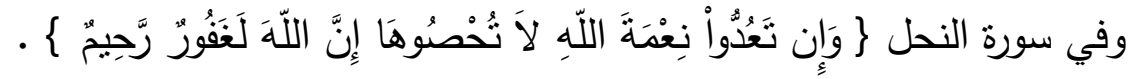
والذي لا جدال فيه أن فاصلة كل من الآيتين تتسجم مع سياقها العام الذي جاءت فيه ففي سورة النحل ، تضمن الحديث عن اله القادر المنعم الذي سخر لنا الليل والنهار والثمس والقمر والنجوم والبحر والجبال وغيرها ...فأتت الفاصلة لتؤكد أن الله غفور رحيم لعجزهم عن إحصاء نعمه . 
أما سورة إبراهيم فتتحدث عن صفات الإنسان ، وجحوده ونكرانه " والكفر باله ، وعدم الاعتراف له بالفضل على نعمه ، ولذلك جاءت الفاصلة في

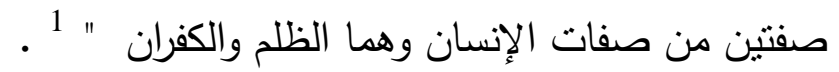

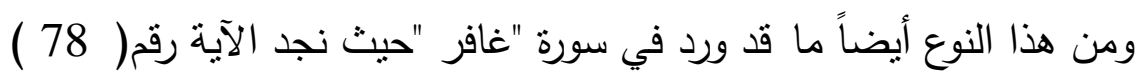

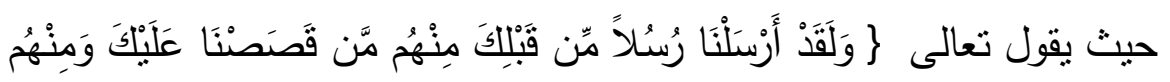

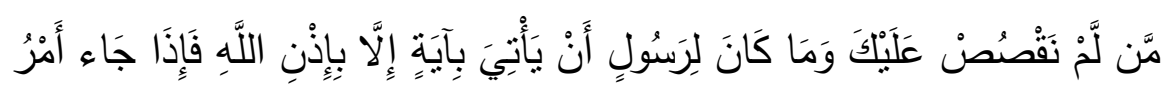

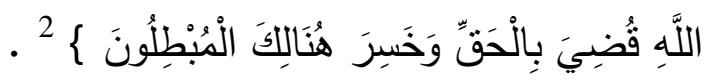

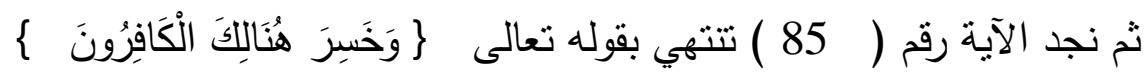

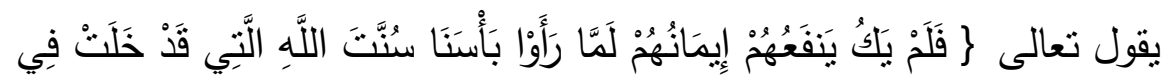

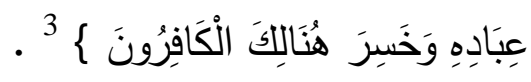

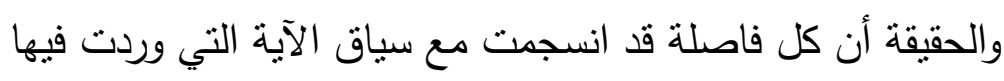

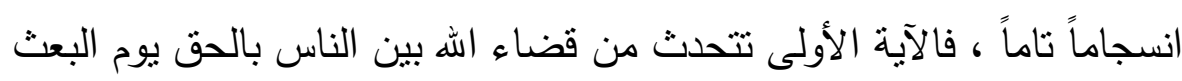

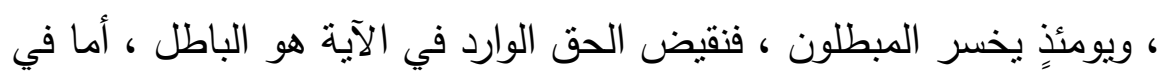

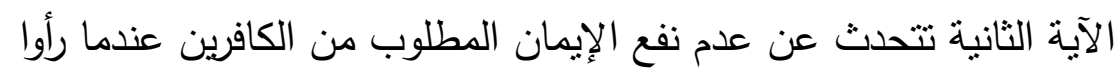

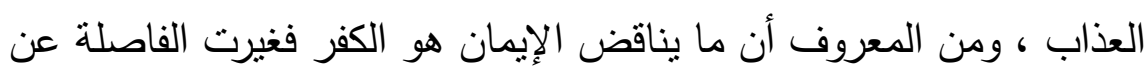

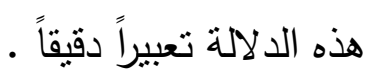

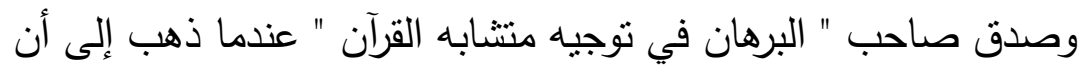

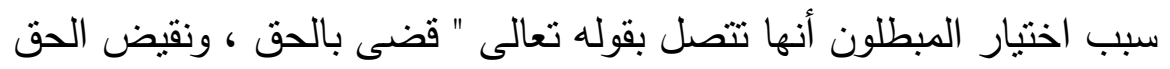

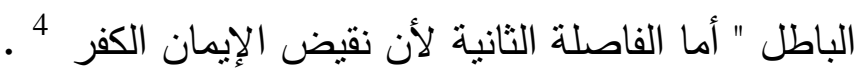

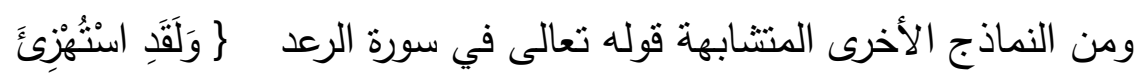

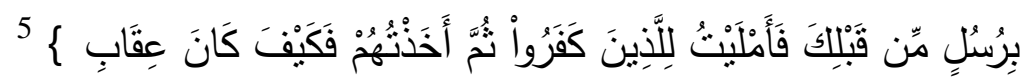




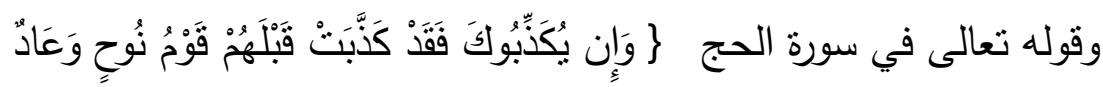

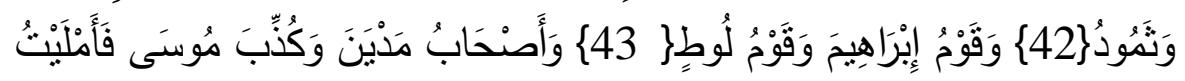

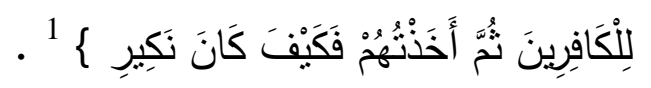

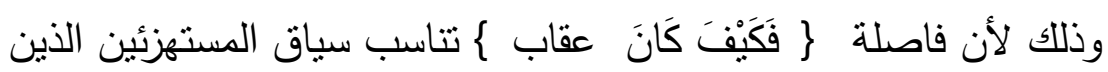

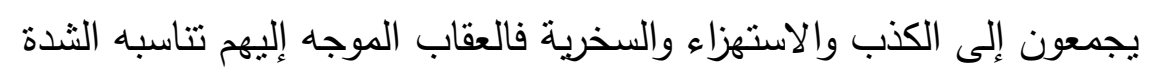

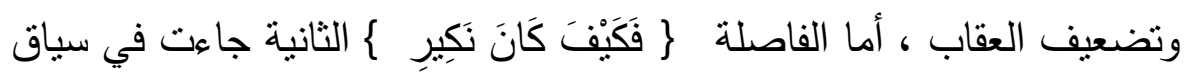

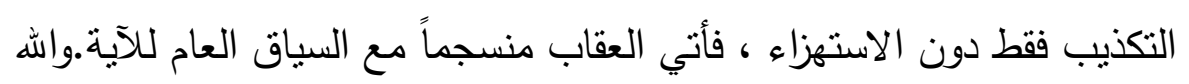
أعلم

\section{4- أسلوب الفواصل والقراءات :}

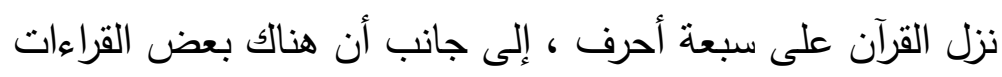

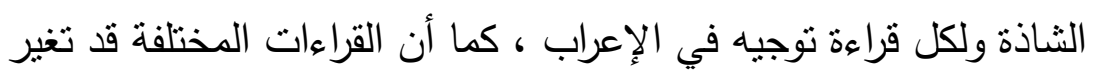

في بنية الكلمة على المستوى الصرفي ، وهو ما يستتبع تغييراً جذرياً للمعنى

وقد تابع العلماء هذه الظاهرة ، لكني سأثنير إلى ما يتطلق بالتغيير

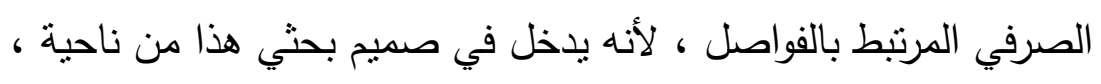

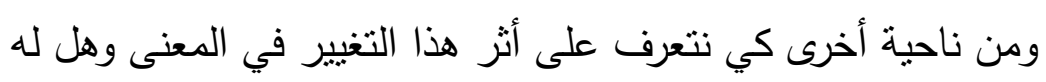

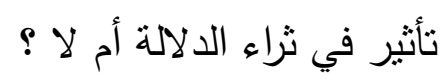

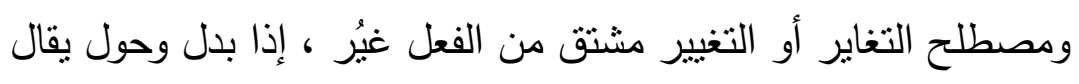

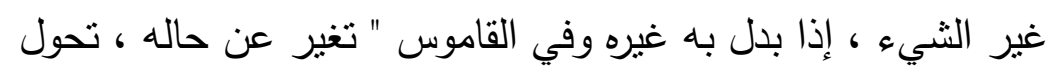
وغيره جطله غير ماكان وحوله وبدله " 1. 1. وهذا التغاير التصريفي ناشئ من اختلاف القراءات من قارئ لآخر تبعاً

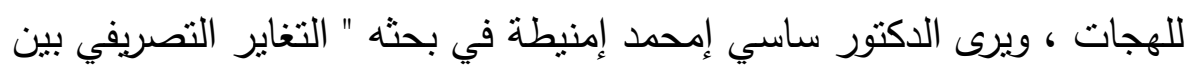

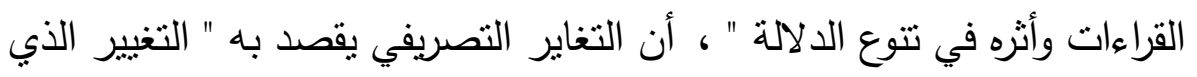


بحدث في صورة الكلمة ، وصيغتها قبل التركيب ، ولما كان ذلك يحدث كثيراً

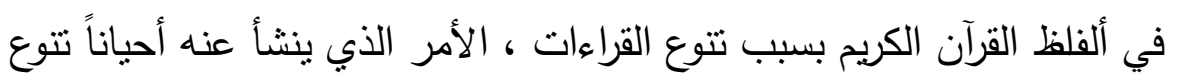
في الدلالة واختلاف في المعنى " 2.

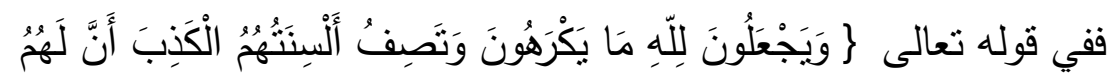

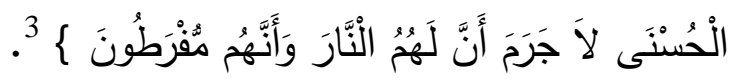
فقد قرأها نافع وأكثر أهل الددينة " مفرطون" بكسر الراء مخفقة ، وقرأها

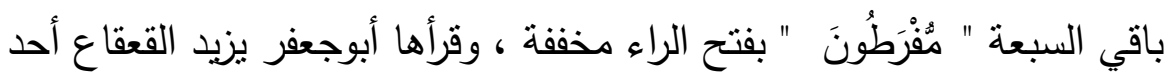

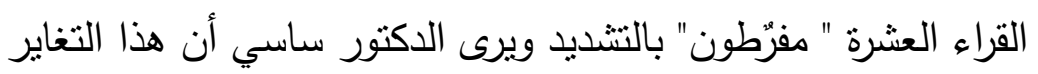

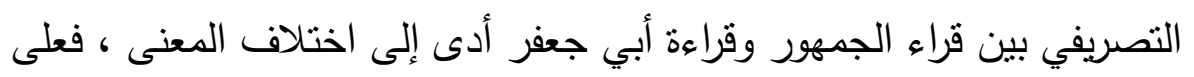

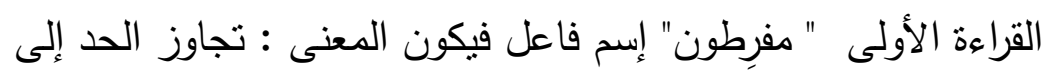

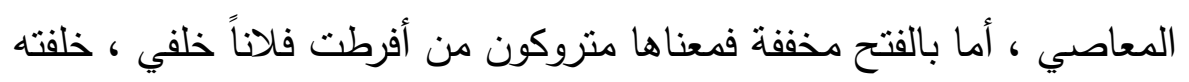

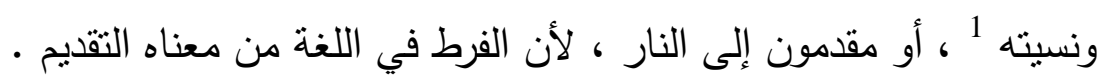

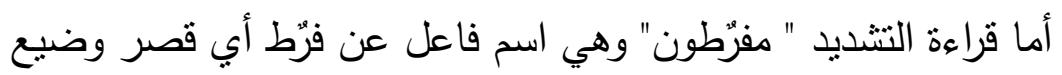
حق الله وعباده . - المان. والواضح أن المعنى قد تغير حسب الوضع الصرفي للكلمة ، وهذا التغاير

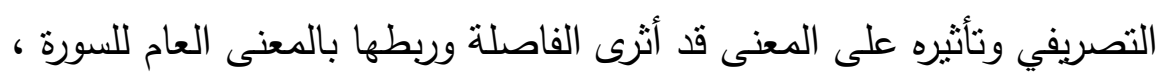

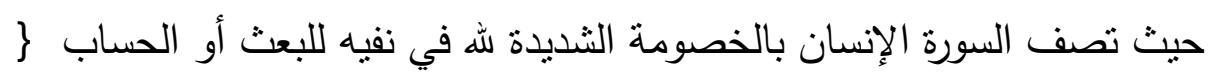

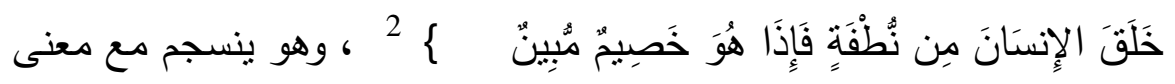

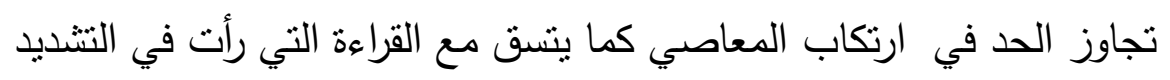

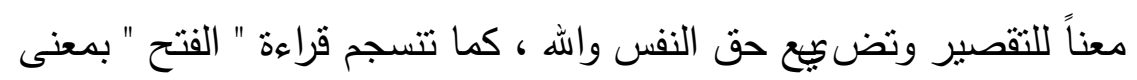

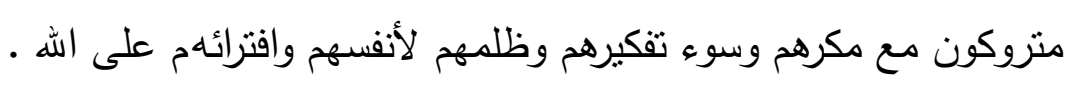




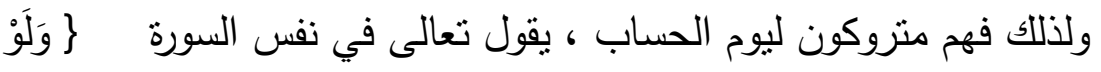

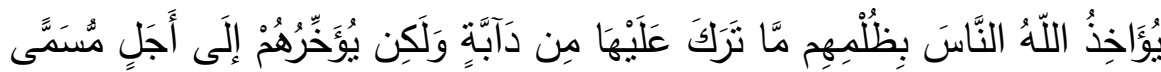

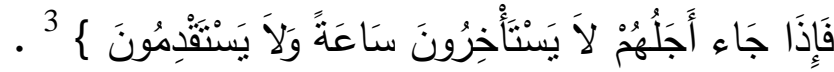

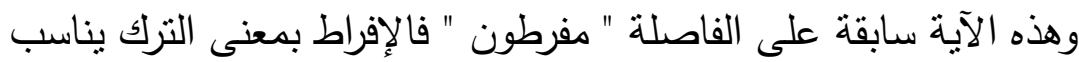

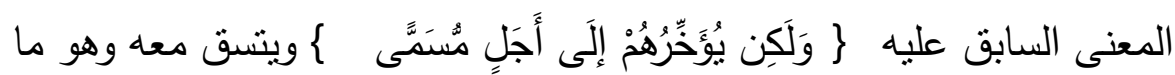

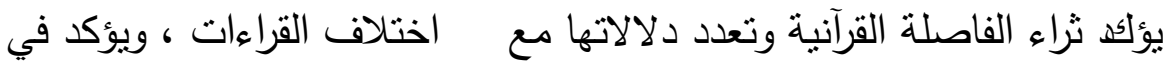
الوقت نفسه أن هذا المبحث في حاجة ماسة إلى دراسة منأنية لبيان مناسبة

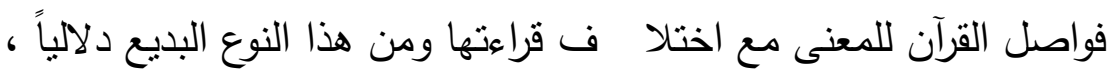

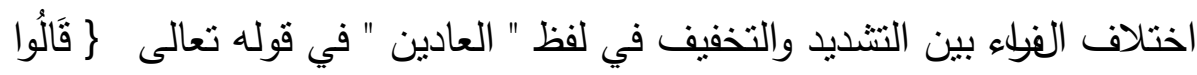

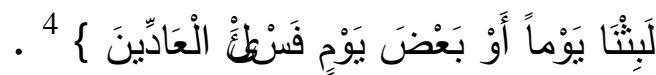

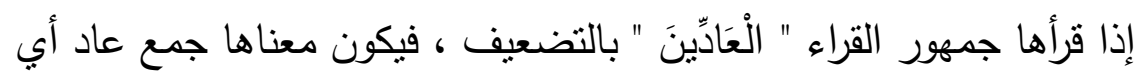

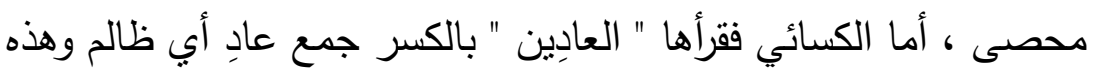

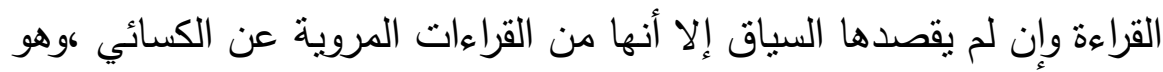

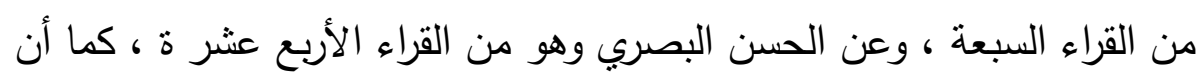

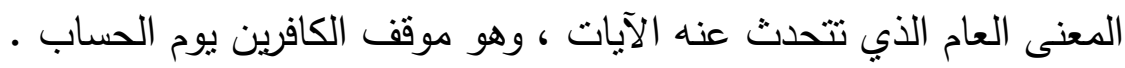
حيث يحاول بعضهم إلقاء اللوم على بعض كما صور القرآن الكريم ذلك بلكابل

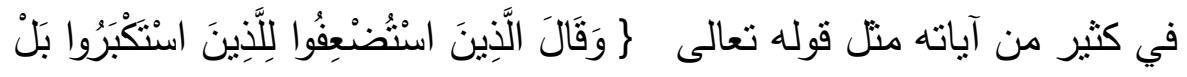

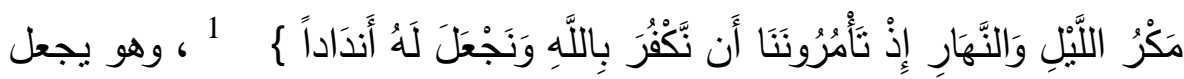

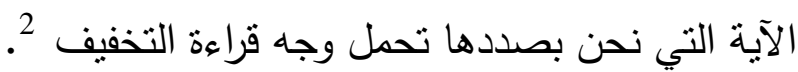

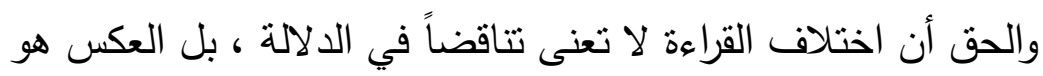

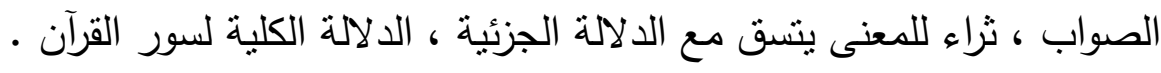


إن المعنى سواء كان المقصود منه العادين بمعنى الحاسبين لعدد السنين ، أو الظالمين لغيرهم ، فينسجم مع المعنى قبله ، لأن الحديث السابق على تلك الآية يدور حول مقارنة بديعة بين فريق المؤمنين وفريق الكافرين .

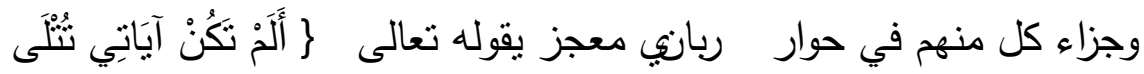

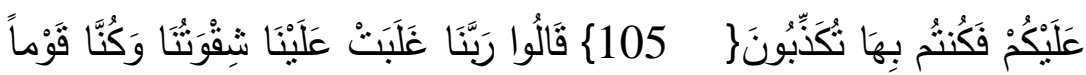

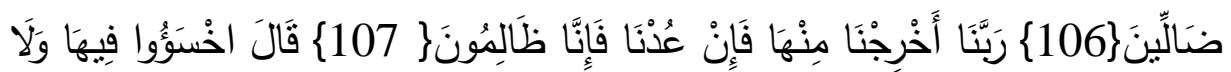

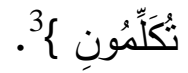
فهذه الآيات بحوارها الثيق تمهد لذلك السؤال وإجابته سواء كانوا يقصدون الحساب أو الظلم ، وهذا من ثراء الفاصلة وتعدد معانيها ودلالتها حسب القراءات

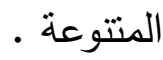
وهو ما يؤكد من جانب آخر إعجاز فواصل القرآن مع اختلاف ونتوع قراءتها

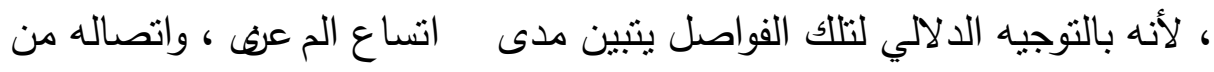
طرف خفي بكل قراءة ، وهو ما يربط القرآن الكريم ، وهو باب من أبواب إعجاز

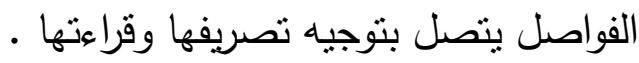

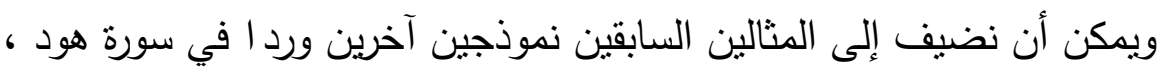

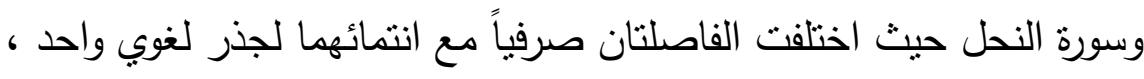

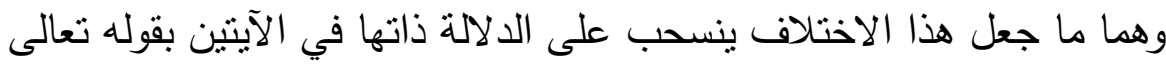

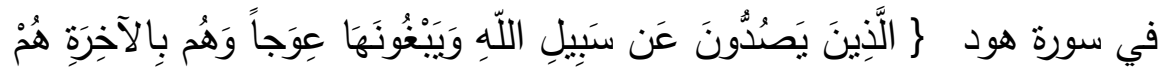

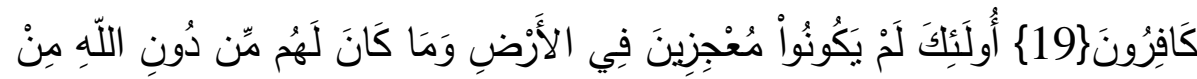

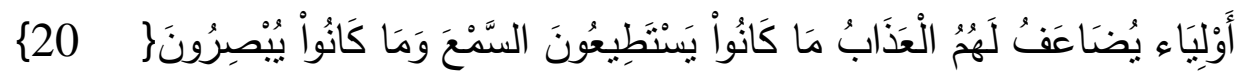

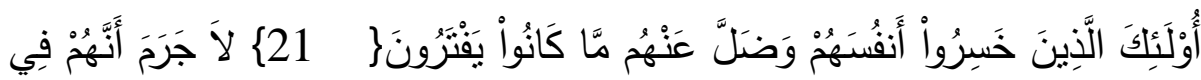

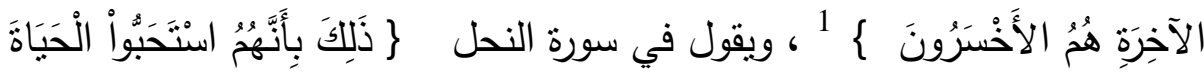

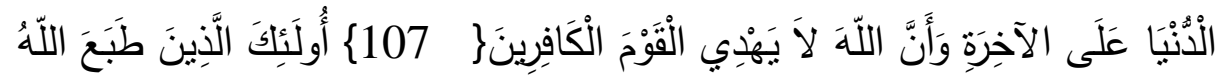




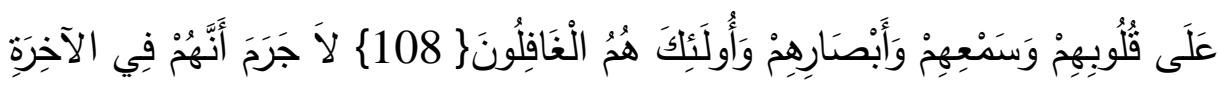

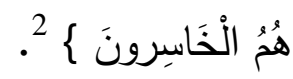

ومما لاثك فيه أن التغييّ التصريفي في الآيتين أتى متسقاً مع الدلالة الكلية

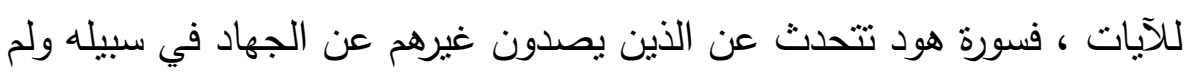

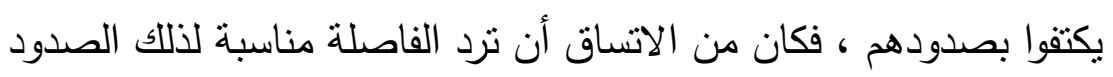

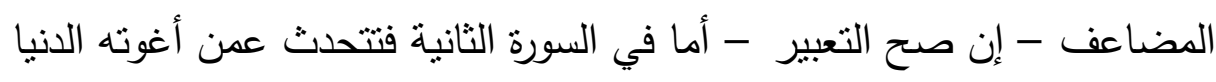

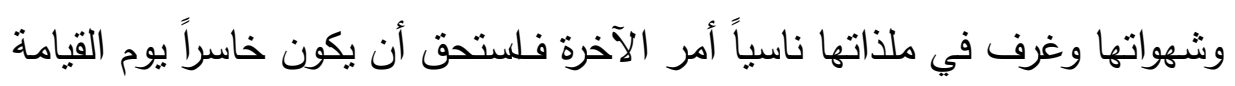

فما أروع أسلوب القرآن ، وما أدق فواصله المعبرة عن السياق والمترابطة معه

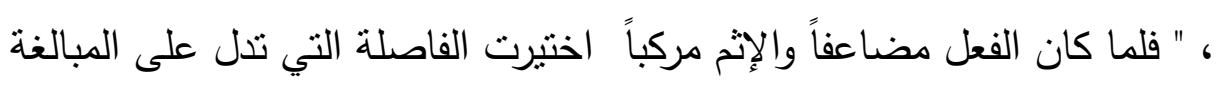

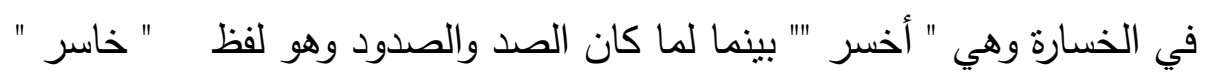
على زنة فاعل .

\section{5-أسباب التكرار في الفواصل :}

وأعني بأسلوب التكرار ، ذلك التكرار الخاص بالفواصل التول القرآنية ، وهو من

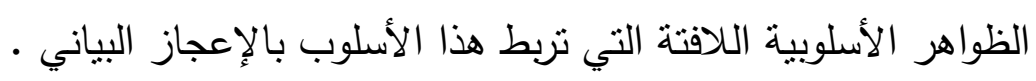

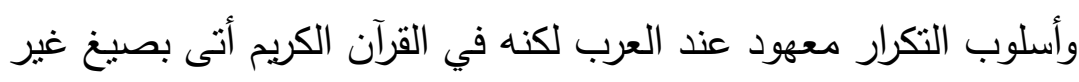

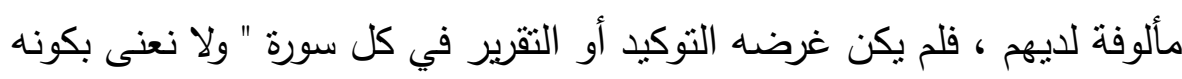
غير مألوف مظنة التنافر والتباعد فهو نكرار يطول إلى حد قد ينتظم السورة كلها

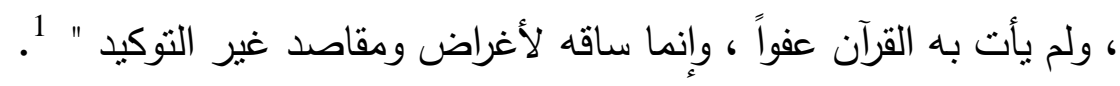

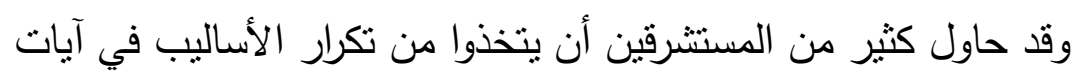

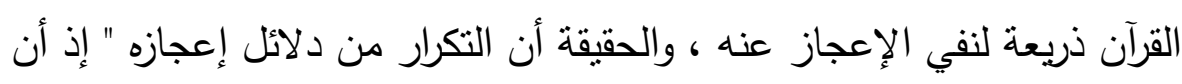

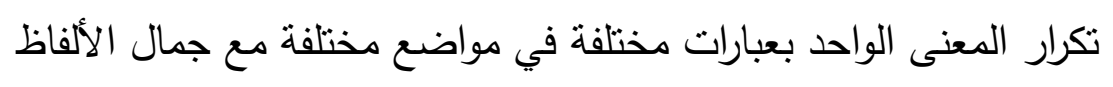

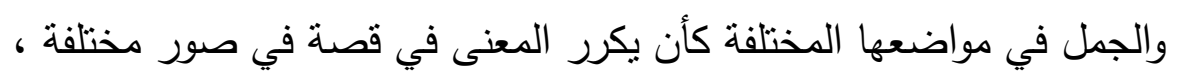


وكل عبارة معجزة في ذاتها ويتحدى بها في نغمها وموسيقاها وألفاظها وجملها ، وعجز العرب على أن يأتوا بأي عبارة منها دليل على كمال الإعجاز في جملته

$$
\text { وفي أجزائها " وعز العرب } 2 .
$$

ومن صور التكرار غير المألوف عند العرب ، ذللك التكرار الوارد في سورة " الرحمن ، القمر ، المرسلات ، الواقعة " حيث تكررت فواصل بعينها تمنت آية

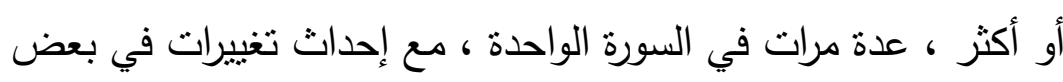
الأساليب والكلمات لغرض بلاغي سنورده في مكانه .

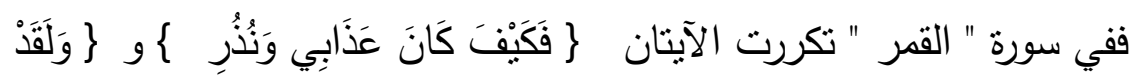

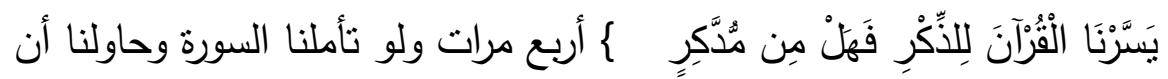
نستشف من السياق العام لآياتها سر هذا التكرار بلسلوبه المعجز ، لتبين لنا أن أن

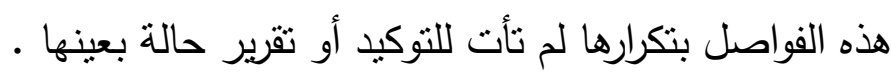
ولنتأمل سياق السورة بآياتها ومعانيها كي نتعرف على سر هذا التكرار المعز ، فالسورة تتحدث بداية في موازنة منعقدة بين كفار قريش تكذييهم

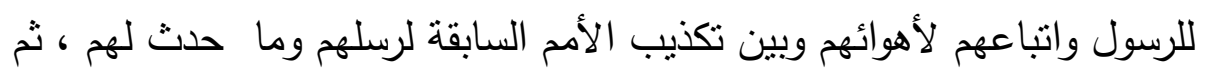

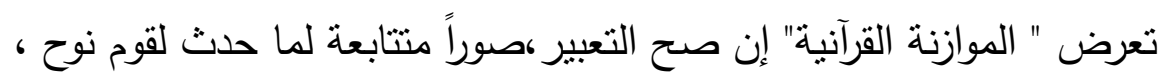
ووصفهم إياه بالجنون وسبهم له، فذعا عليهم فاستجاب الله دعاءه فَفَتَحْنَا

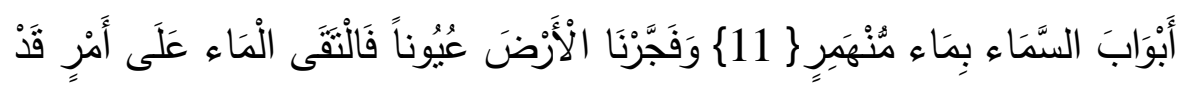

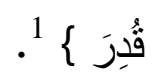
لتأتي الفاصلة الأولى كالخاتمة المتوقعة كي تعطي العظة والعبرة بعد هذه الآية التي يجب أن تحرك عقول وقلوب من يعتبر ويتعظ .

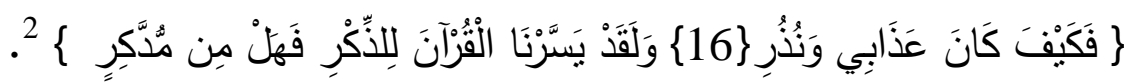
وتتكرر نفس الصورة بفاصلتها مع قوم عادٍ ، ومع قوم ثمود وتكذييهم لسيدنا صالح رغم إنذاره لهم ، فقتل صاحبهم ناقة الله التي أخرجها لهم من الصخرة، 


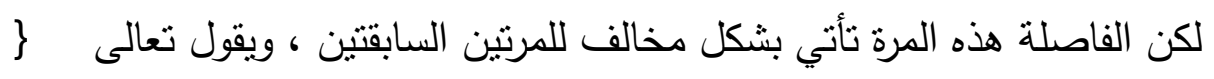

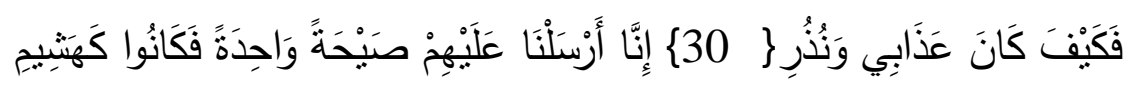

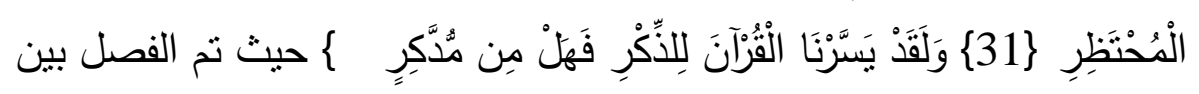

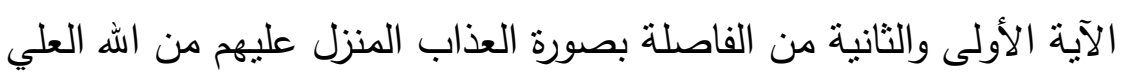

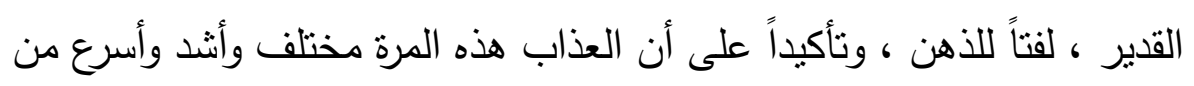

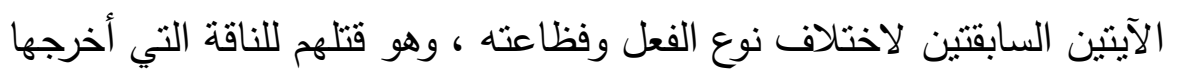

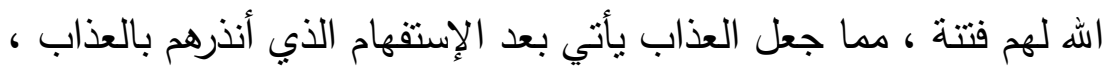

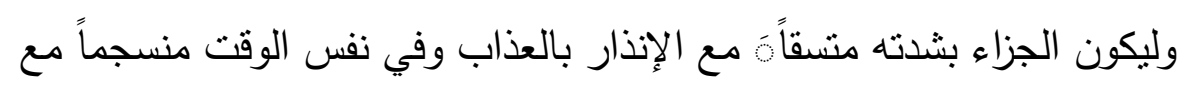

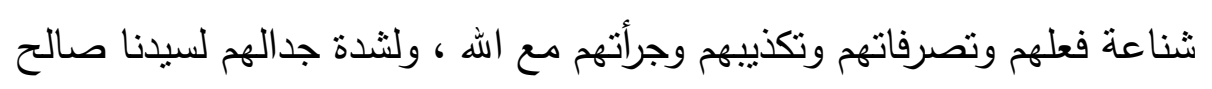
، ووصفهم له بالكذب والتكبر ، ثم قتلهم للناقة . كل ذللك كان يوجب أن يكون الجزاء سريعاً دون تمهل لثدة عنادهم وكفرهم

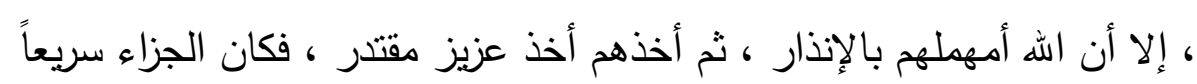

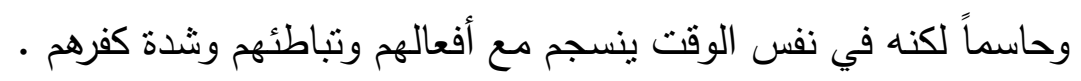

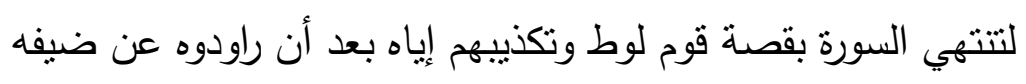

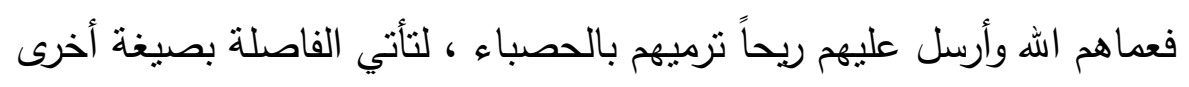

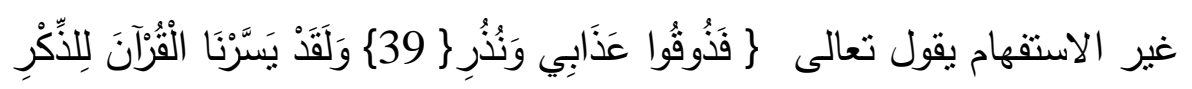

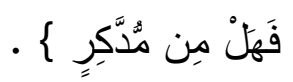

ولابد أن لتغيير بداية الفاصلة من " كيف كان عذابي ونذر " إلى تلكل

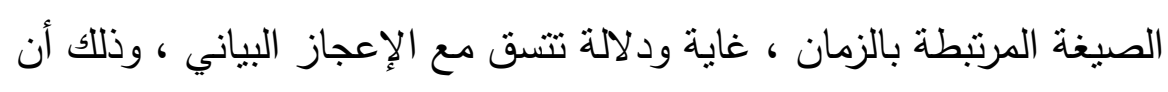

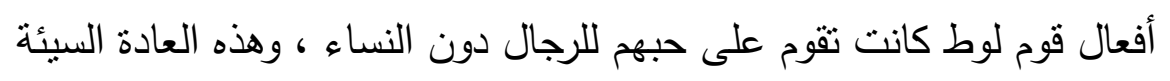

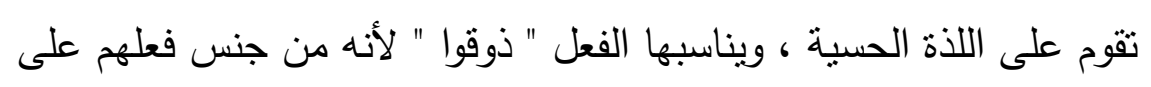

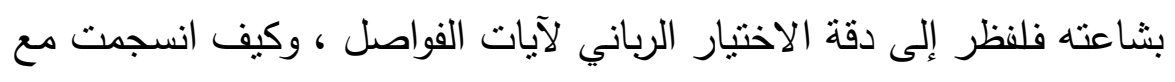

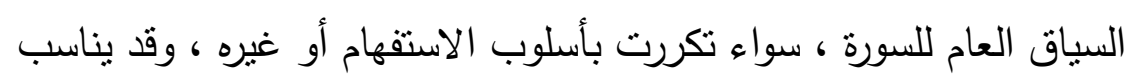


الفعل " ذوقوا " طمس اله لأعينهم وهو حاسة من الحواس يتألم الإنسان كثيراً إن فقدها ويواجه صعوبات جمة في حياته والله أعلم .

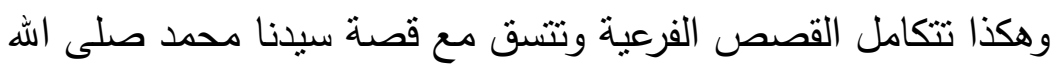
عليه وسلم ، لتمد من يقرأها بجرعة إيمانية كبيرة من خلال ماتحويه من قصص في التصن انتهت خاتتتها بتلك الفاصلة المزلزلة لكيان المؤمن الذي يريد أن يتعظ ويعتبر.

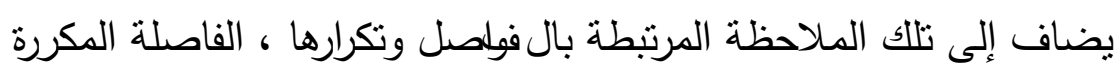

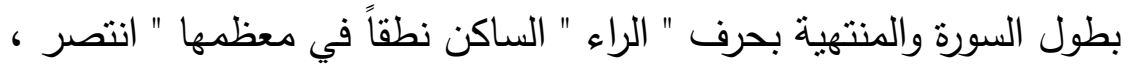

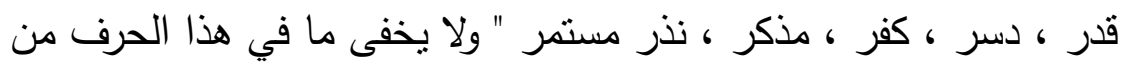

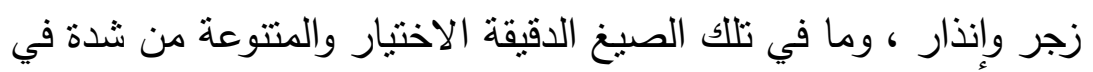

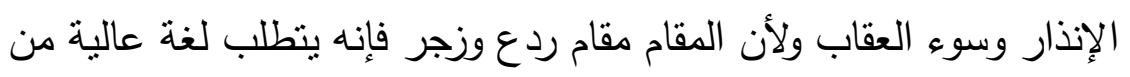

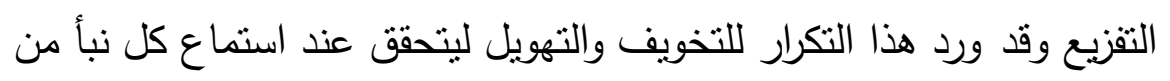
أنباء الأولين إنذاراً واتعاظاً 1.

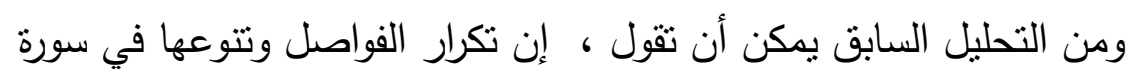

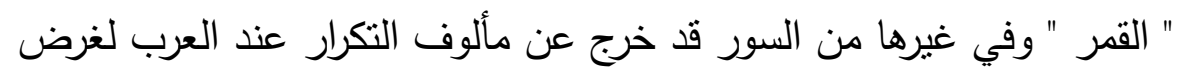

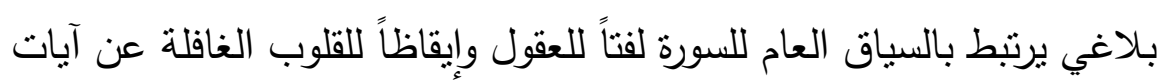

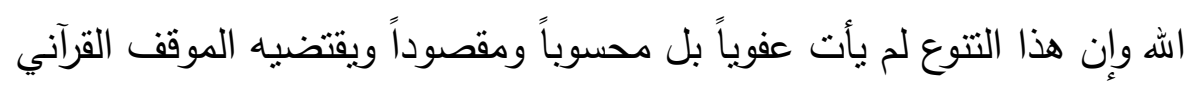

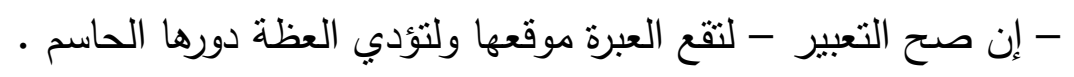
وصدق الدكتور عبدالقادر رزق الطويل حين ذهب على أن " تفرد القرآن

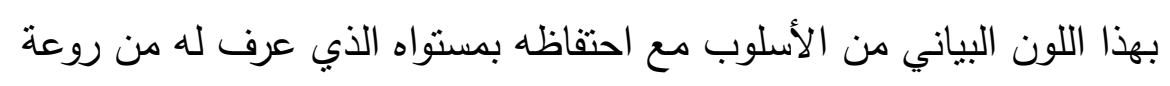
النظم وجماله وانساق نغمة - هو - في حد ذاته - شهادة قائمة للبيان القرآني

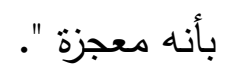

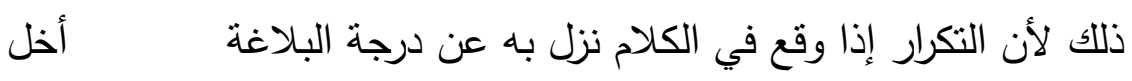

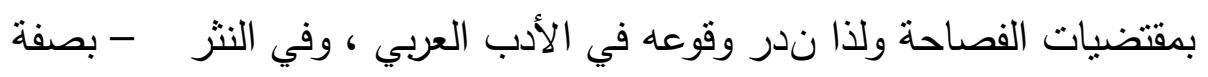


خاصة - لأنه يسقطه ولا يحسب من البلاغة ، أما في القرآن فلم يحدث فيه

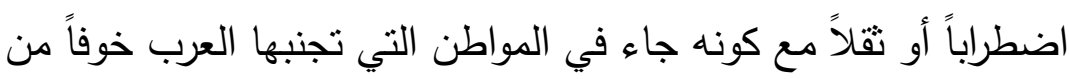

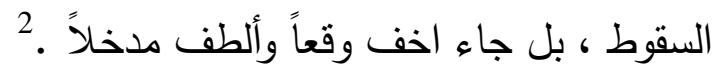
7- أسلوب الفواصل والإيقاع :

يرتبط موضوع الإيقاع بالبحث السابق عن تكرار ارتباطاً وثيقاً إذ تبين لنا

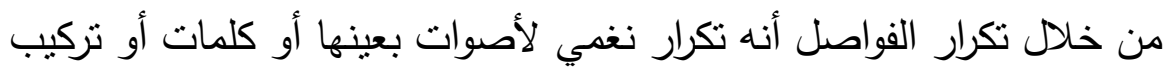

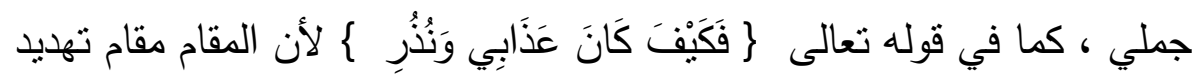

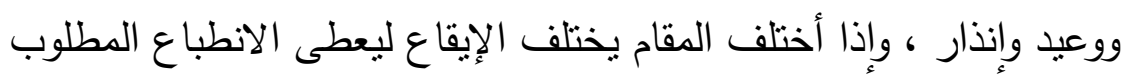

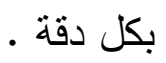

ولما كانت الفاصلة القرآنية وتكرارها هي المنوطة بالبحث ، تربط تكرارها

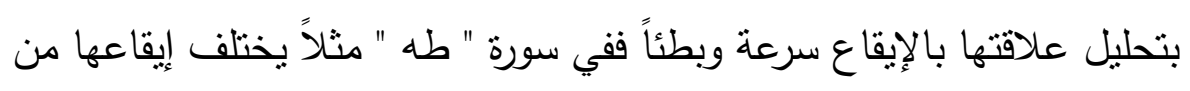

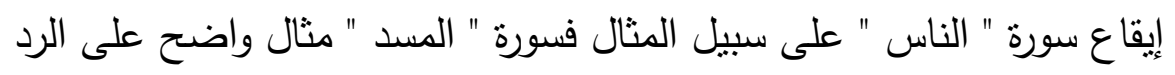

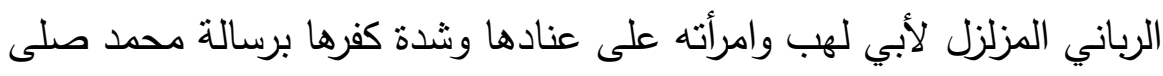

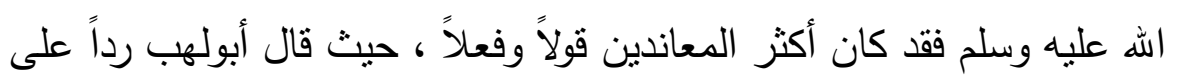

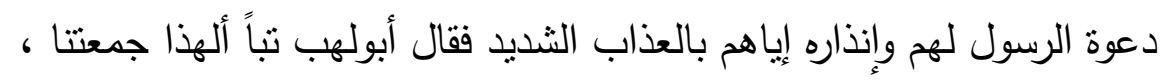

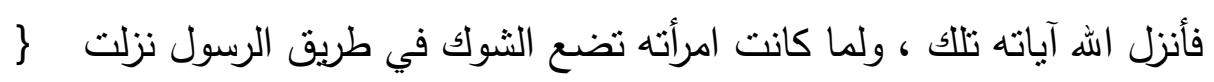

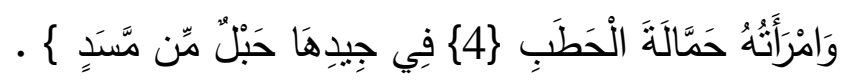

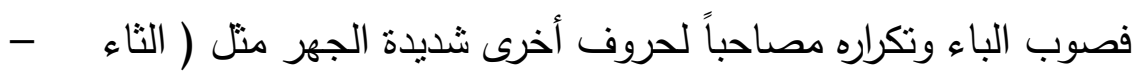

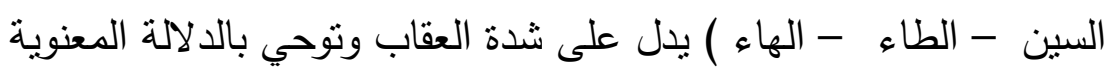

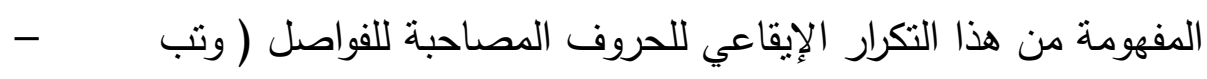

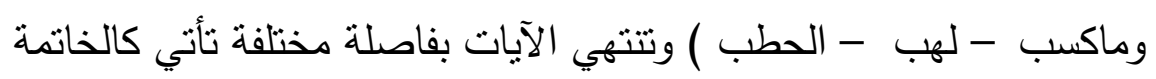

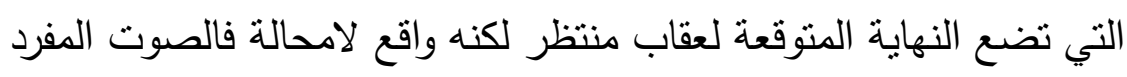

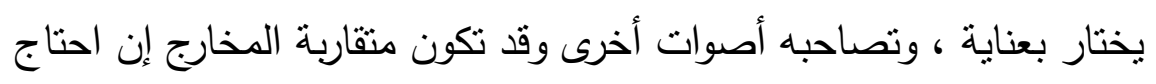


الموقف ذلك وقد تكون متباعدة المخارج إن كان التباعد أدل على المعنى ،

$$
\text { وأكثر تصويراً له } 1 .
$$

وصوت الباء وهو من الأصوات الثديدة المهجورة ، تتاسب موقف

التهديد والوعيد ، وما فيه من زجر وإنذار وتخويف فسورة المسد تتحدث عن تهديد ووعيد حاصل لامحالة ، فلا يناسب هذا التهديد غير هذا الصوت الثديد المهجور ، والذي تصاحبه أصوات أخرى تسانده وتؤدي نفس الدلالة كما سبق.

ولو أقمنا مقارنة سريعة بين اختيار هذا الصوت ، وبين اختيار فاصلة

سورة " الناس " مثناً لوجدنا أن فواصل سورة الناس تتتهي بحرف السين وهو من الحروف المهموسة الصفيرية والتي ينطلق منها الصفير بسبب صيغة فتحة الانفتاح حين ننطق هذا الصوت الاحتكاكي 1. وصوت السين يناسب مقام الوسوسة التي يحاول عن طريقها إبليس أن يبعد الإنسان عن رحاب ربه وأن يقويه بارتكاب الآثام ، " وهو أدل بجرسه

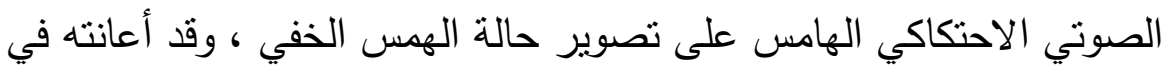
ذلك بعض الأصوات الأخرى التي تقاربت معه مخرجاً ، ومنها الصاد المطبق الهن الذي يشترك في كل خصائصه الصوتية مع صوت السين ، وهو يعطي جرساً أعلى وسط السينات المتتالية ويشترك معه صوت الفاء وهو صوت مهموس شفوي سني احتكاكي " 2. هكذا تتعاضد الأصوات لتتبئ بجو الهمس الخفي ولتحرك وتدفع الدلالة تجاه الوسوسة ولتحقق معنى الاخول الخفي المناسب لإبليس • أما تكرار الجميل كفواصل متساوية وسريعة ، لاستحضار صورة معينة وتجسيمها من خلال الإيقاع بنوعية السريع والبطيء فقد ورد في سورة العاديات

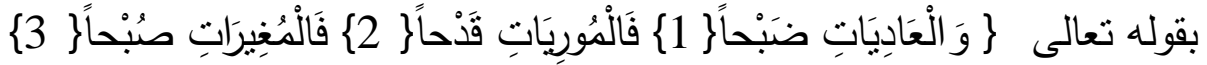

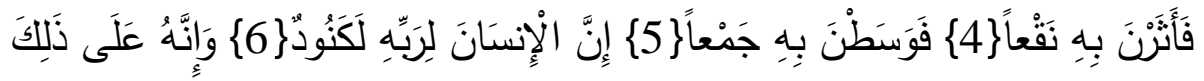




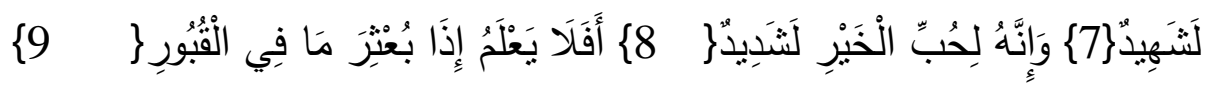

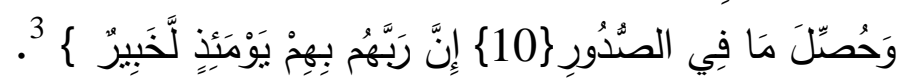

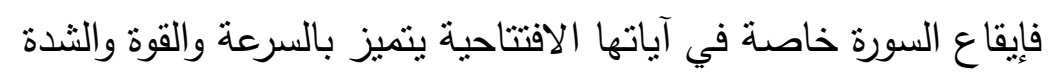

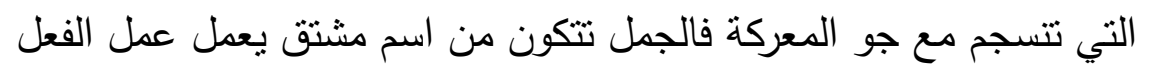

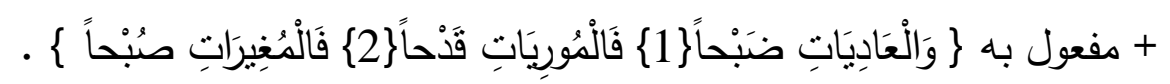

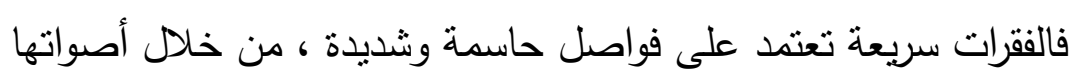

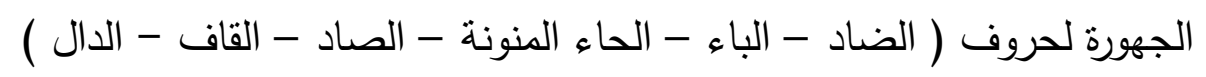

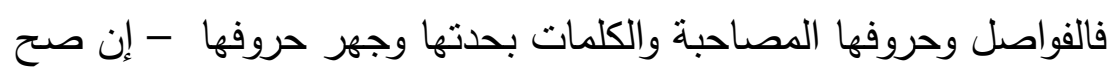

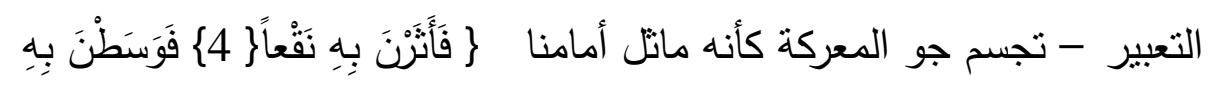

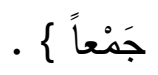

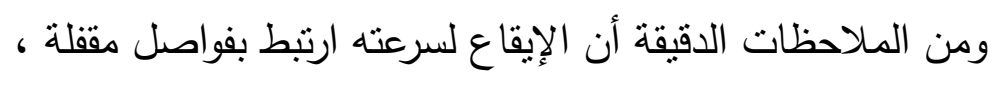

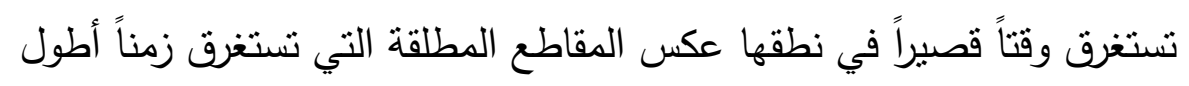

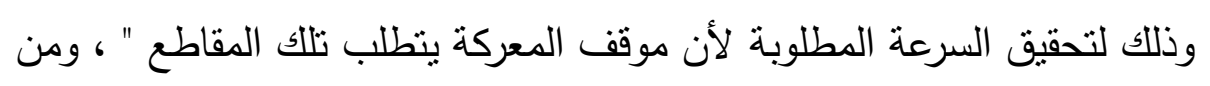

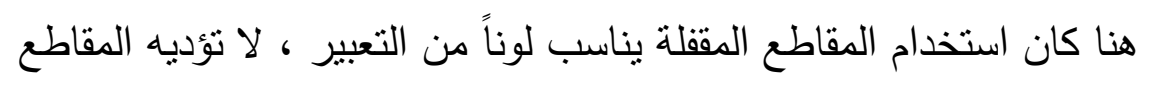

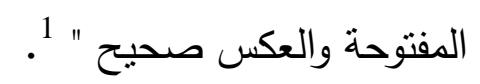

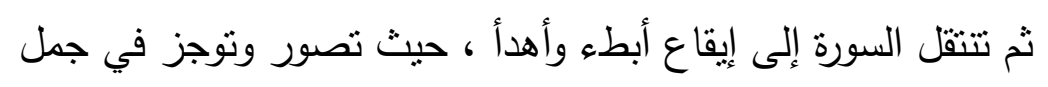

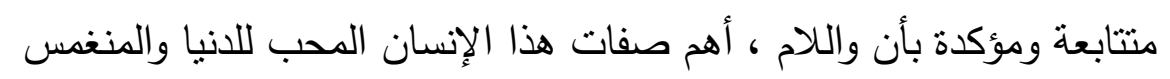
في ملذاتها ناسياً حقوق ربه وجاحداً بشدة لأنعمه .

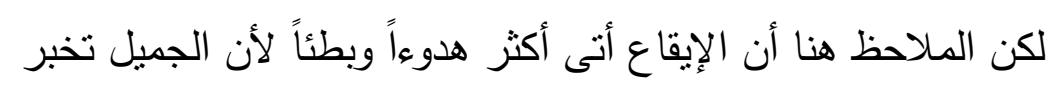

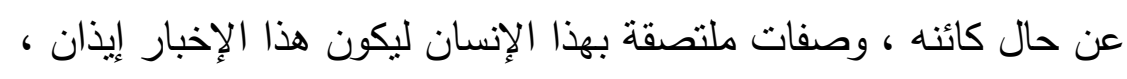

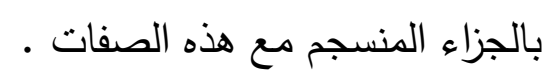
فالآيات من 1-5 إيقاعها سريع لأنها تتحدث عن جو المعركة وما فيه من أصوات وغبار والتحام وتوسط للجموع ، ومن ثم أتت الجمل قصيرة 
ومتتوعة بين الاسمية والفعلية والآيات من 6-8 إيقاعها أقل سرعة لأنها جمل

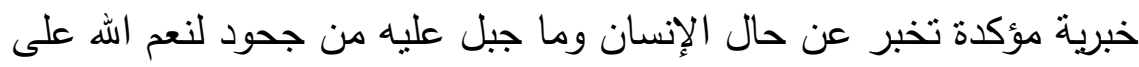
الرغم من كثرتها والآيات من 9-11 إيقاعها أسرع يناسب الإيقاع ويرتبط دلالياً

لكن من العلاقة الخطية التي تربط الإيقاع السريع في بداية السورة

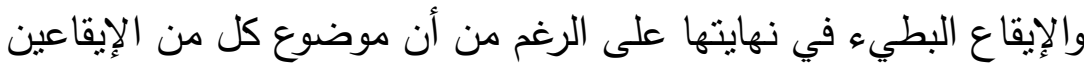

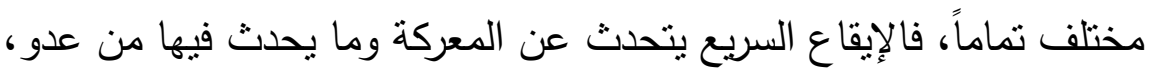
وإغارة ، وإثارة للغبار ، وتوسط لجموع المتحاربين إلخ ، والإيقاع الثاني يتحدث عن الإنسان وجحوده وبعثه وحسابه .

ومن خلال التحليل الدقيق ، نجد علاقة خفية لكنها قوية تربط هذا

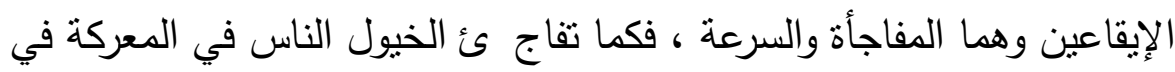
سرعة كذللك يوم القيامة سيفاجأ الناس بنفس السرعة بل وأسرع مما يتصوره

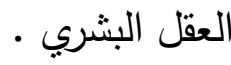

فهل تكون سورة العاديات بإيقاعها السريع والأقل سرعة تصوير قرآني

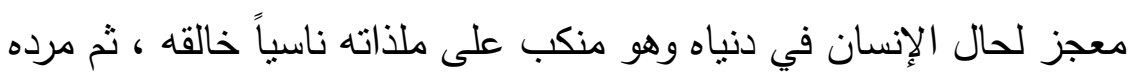

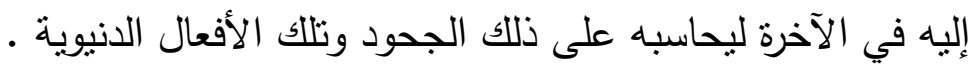

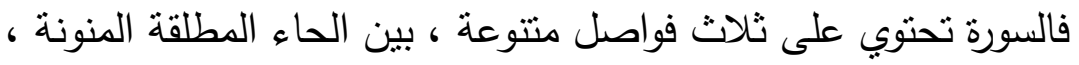

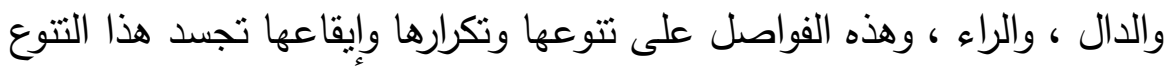
واختلاف مصير الإنسان بين دنياه التي يعيش فيها عابثاً لاهياً وبين آخرته

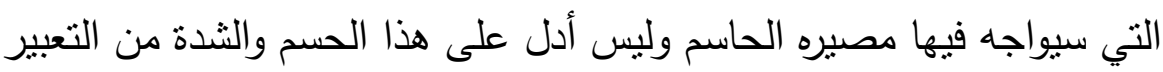
بالأفعال مبنية للمجهول مشددة في قوله تعالى : 


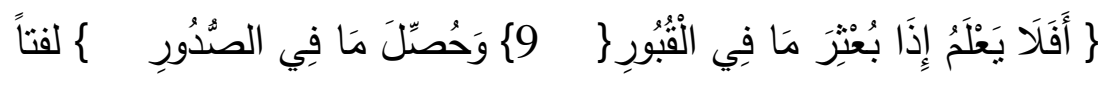

للأهن للحدث نفسه وتركيزاً له ، أما التثديد فدلالته واضحة على فئل شدة الزجر

والهه أعلم 


\section{نتائج البحث}

1 - إن مبحث الفاصلة في القرآن الكريم من المباحث الهامة التي تؤكد

ثراء ألفاظ القرآن ومعانيه .

2 - إن الفاصلة القرآنية ترتبط بإعجاز البيان القرآني ارتباطا وثيقاً ، حيث

اتضح ذلك من خلال علاقتها بالسياق العام للسورة وليس من خلال

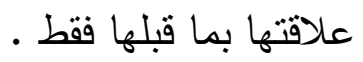

3 - إن الدارسة الأسلوبية للفواصل القرآنية ، من الدراسات الخطية التي بلي

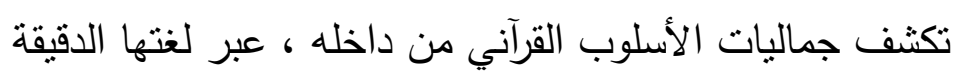

بألفاظها الموحية وجملها البليغة وعباراتها الآسرة .

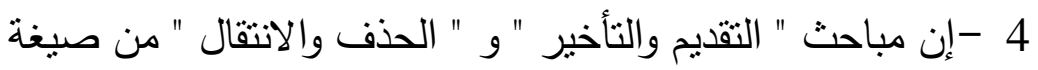

الإفراد إلى الجمع " أو العكس قد أكدت مدى ارتباط الفي الفاصلة بالسياق

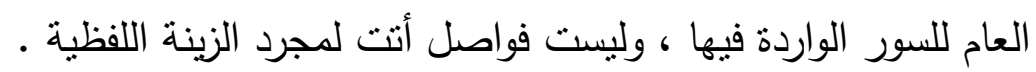

5 - 5 إن هناك التغيير لثراء الفاصلة وتعدد تأويلها حسب القراءة وهذا

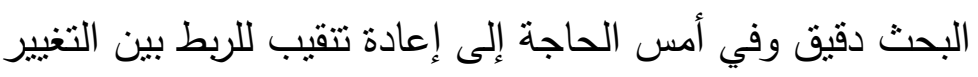

التصريفي للفاصلة وبين خصوبة دلالتها المرتبطة بالسياق العام .

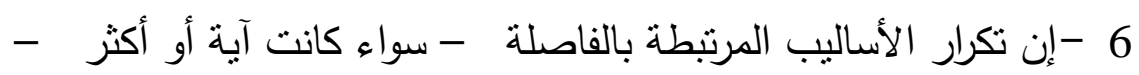

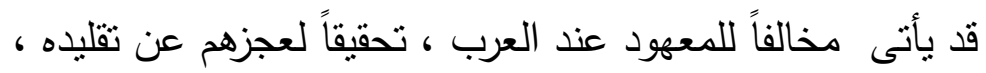

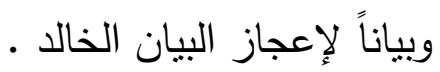

7 - إن الإيقاع سواء كان مرتبطاً بالحروف أو تكرار كلمات أو جمل لئان

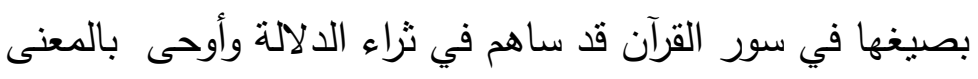

المرتبط بهذا الإيقاع في سرعته وبطئه . 
1 1 ابن منظور الإفريقي " لسان العرب " .

2 أبوحيان الأندلسي " الحبر المحيط " . 3 آب الأثير " المثل السائر " .

4 كبن سنان الخفاجي " سر الفصاحة " . 5 كلباقلاني " إعجاز القرآن " مؤسسة الكتب الثقافية بيروت . 6 6لرومانى "النكت فى إعجاز القرآن" تحقيق د/ محمد خلف الله، د/ محمد زغلول سلام - دار المعارف مصر · 7 tلزمخشري " تقسير الكثاف " دار الكتاب العربي جـ 1 . 8 كالسيوطي " الإتقان في علوم القرآن " دار الهدى الجزائر جـ1 . 9 +لكرمانى "البرهان فى تأويل منشابه القرآن" دار القلم بيروت.

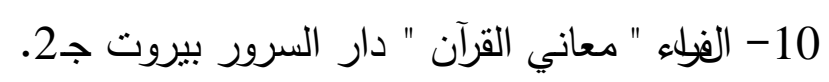

11- النيسابوري "غرائب القرآن ورغائب الفرقان " المكتبة القديمة القاهرة جـ1.

12- أحمد أبو زهرة المعجزة الكبرى ، دار الفكر العربي 1988 ـ 13- د ـ جاسم محمد " النسق الإيقاعي في الفاصلة القرآنية " مجلة كلية الدعوة الإسلامية طرابلس لييا 2006 . 14- جلال الدين السيوطي " تفسير الجلالين " دار المعرفة بيروت. 15- د . يالي محمود سليمان " الفاصلة القرآنية وأثزها في السياق " ماجسنير جامعة المرقب ليبيا كلية العلوم والآداب ترهونة 2005-2006 ـ 16- د/ عائشة عبد الرحمن "الإعجاز البياني للقرآن" دار المعارف القاهرة. 17- د/ عبد الرزاق رزق الطويل " دراسات في البيان القرآني " دار البيان القاهرة. 18- عبد القاهر الجرجاني " دلائل الإعجاز ". 19- عبد الكريم الخطيب " إعجاز القرآن " دار الكتاب العربي مصر. 20- د/ طه حسين " من حديث الثعر والنثر " دار المعارف مصر. 
21- د / ساسي إمحمد " التغاير التصريفي في القراءات " مجلة كلية الدعوة الإسلامية طرابلس ليبيا 2006 .

22- د / فتحي أحمد عامر " المعاني الثانية في الأسلوب القرآني " منشأة

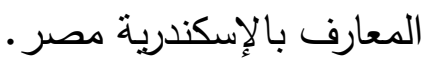

23- محمد أبو زهرة " المعجزة الكبرى " دار الفكر العربي 1988 ـ

24- د/ محمد رمضان الجربى "البلاغة التطبيقية علم البديع" دار إلجا مالطا

1 - ينظر على سبيل المثال ، الباقلاني " إعجاز القرآن " بيروت ص 55 ـ

القراء " معاني القرآن " دار السرور بيروت جـ 2 ص صل 168 ـ .

الينسابوري " غرائب القرآن ورغائب الفرقان " المكتبة القديمة القاهرة ج، 1 ص 425

1- الرماني " النكث في إعجاز القرآن " تحقيق د ـ محمد خلف اله وزغلول سلام ،

دار المعارف مصر ص 102 .

2- ابن منظور الإقريقي ، لسان العرب جـ 7 ص صل 41 .

1 - 2 - سورة البقرة من الآية 11- 13 - 13 ـ

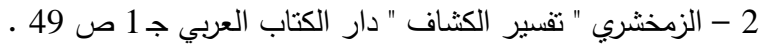

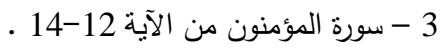

3- السيوطي " الإتقان في علوم القرآن " دار الهدى الجزائر جـ ص ص 120 ـ .

1 - سورة فصلت الأية 3 .

20 - سورة النساء الآية 82 .

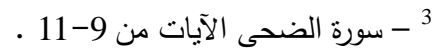

4 - الأستاذ الدكتور " طه حسين " من حديث الشعر والنثر ، دار المعارف مصر ص25 ـ 25

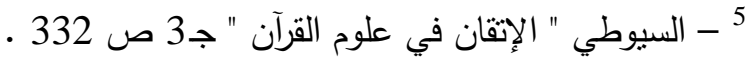

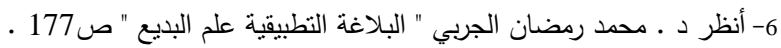

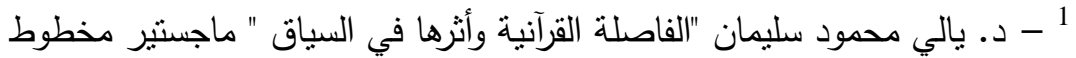

جامعة المرقب ، كلية الآداب والعلوم ترهونة 2005 -2006 ف ص ص 92 ـ 


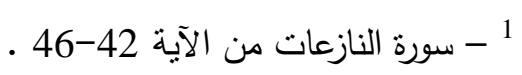

2 - أنظر الزمخشري تفسير الكثاف جـ 4 ص 699 ـ 69

3 - سورة النازعات من الآية 26- 31 - 31 ـ النظريز

4 - أنظر ديالي محمود "ا لفاصلة القرآنية وأثرها في السياق " ص 36 ـ 98 ـ

1

2 - سورة النازعات الآية 25 .

1 - سورة طه من الآية 70 - 71 .

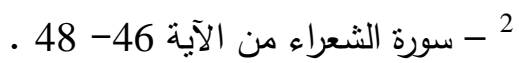

3

1 - د ـ جسام محمد " النسق الإيقاعي في الفاصلة القرآنية " مجلة كلية الدعوة الإسلامية

طرابلس 2006 ص 149 .

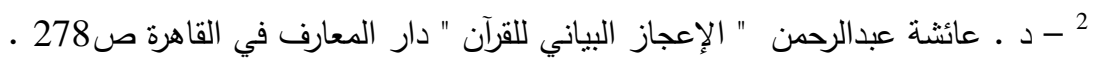

1

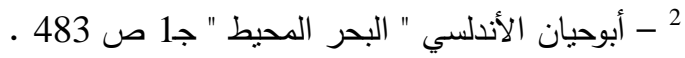

3 - عبدالقاهر الجرجاني " دلائل الإعجاز " ص 525 ـ

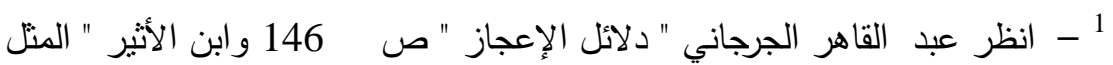

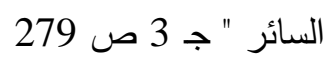

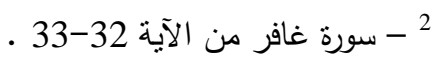

3 - انظر الزمخشري " تفسير الكثاف " ص 165 ـ

4

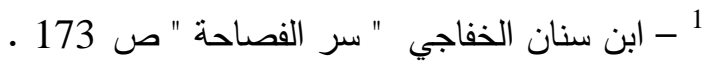

4

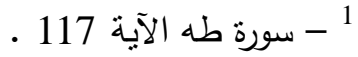

2 - عبدالكريم الخطيب " إعجاز القرآن " في دراسة كاشفة لخصائص للبلاغة العربية

، دار الكتاب العربي مصر ص 220.

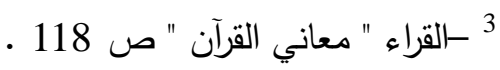

1 -ـــ ـ جاسم محمد " النسق الإيقاعي في الفاصلة القرآنية " ص 165 ـ . 


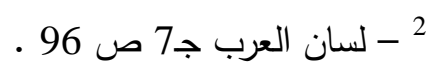

3 - د ـ ـ جاسم محمد سهيل " المنسق الايقاعي في الفاصلة القرآنية " مجلة الدعوة

$$
\text { الاسلامية عدد } 23 \text { ص } 167 \text {. }
$$

1 صورة الجانية الآية 15 .

2 - سورة فصلت الآية 46 .

3

1 - د ـ جاسم محمد " النسق الإيقاعي في الفاصلة القرآنية " ص 158 ـ ـ 156

2 - سورة غافر الآية 78 .

3 - سورة غافر الآية 85 .

4 - أنظر الكرماني " البرهان في توجيه منشابه القرآن " دار القلم بيروت ص166 166 ـ

$$
\begin{aligned}
& 5 \\
& 4 \text { - سورة الحج من الآية 42- } 44 \text { ـ } 42 \text {. }
\end{aligned}
$$

1 - مجد الدين بن يعقوب الفيروز أبادي " القاموس الدحيط " . ل

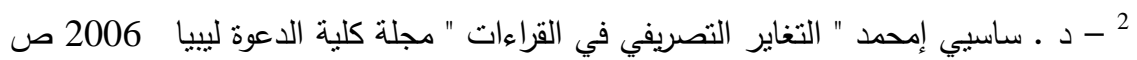

3

1 - أنظر إلى عبيدة " مجاز القرآن " ج1 صل ص 361 ـ 361 .

2 - سورة النحل الآية 4 .

3 - سورة النحل الآية 61 .

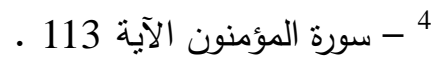

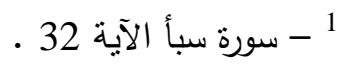

2 - د ـ ساسي إمحد " التغاير التصريفي بين القراءات " مجلة كلية الدعوة الإسلامية ص 280 ص 280

3

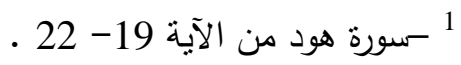




$$
2 \text { - سورة النحل من الآية } 107 \text { - } 109 \text { - } 109
$$

3

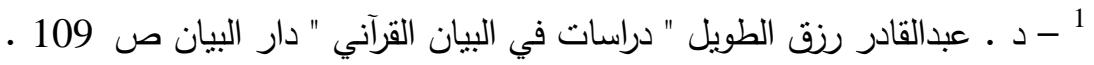

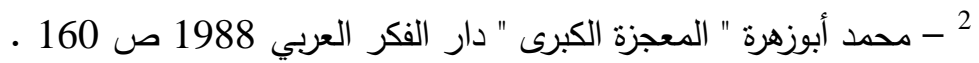

1 - سورة القمرة من الآية 11- 12 - 11 .

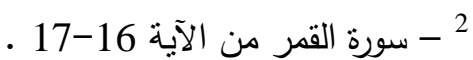

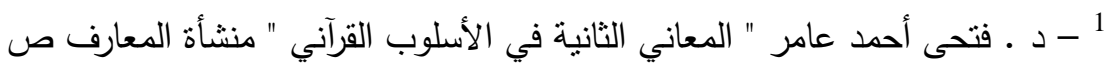

2 2 - د ـ عبدالقادر رزق " دراسات في البيان القرآني " .

1 - أنظر " تفسير الجلالين " دار المعرفة بيروت ص 830 ـ 830

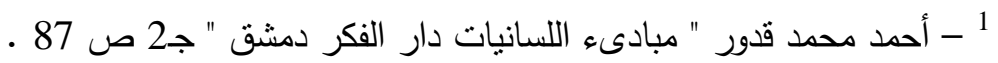

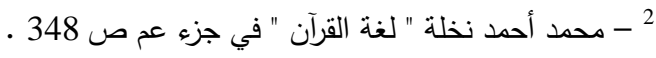

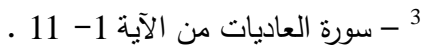

